1992

\title{
A genetic classification of floodplains
}

G C. Nanson

University of Wollongong, gnanson@uow.edu.au

J C. Croke

University of Wollongong

\section{Publication Details}

Nanson, G. C. \& Croke, J. C. (1992). A genetic classification of floodplains. Geomorphology, 4 (6), 459-486.

Research Online is the open access institutional repository for the University of Wollongong. For further information contact the UOW Library: research-pubs@uow.edu.au 


\title{
A genetic classification of floodplains
}

\begin{abstract}
Floodplains are formed by a complex interaction of fluvial processes but their character and evolution is essentially the product of stream power and sediment character. The relation between a stream's ability to entrain and transport sediment and the erosional resistance of floodplain alluvium that forms the channel boundary provides the basis for a genetic classification of floodplains. Three classes are recognised: (1) highenergy non-cohesive; (2) medium-energy non-cohesive; and (3) low-energy cohesive floodplains. Thirteen derivative orders and suborders, ranging from confined, coarse-grained, non-cohesive floodplains in highenergy environments to unconfined fine-grained cohesive floodplains in low-energy environments, are defined on the basis of nine factors (mostly floodplain forming processes). These factors result in distinctive geomorphological features (such as scroll bars or extensive backswamps) that distinguish each floodplain type in terms of genesis and resulting morphology. Finally, it is proposed that, because floodplains are derivatives of the parent stream system, substantial environmental change will result in the predictable transformation of one floodplain type to another over time.
\end{abstract}

\section{Keywords}

classification, floodplains, genetic

\section{Disciplines}

Medicine and Health Sciences | Social and Behavioral Sciences

Publication Details

Nanson, G. C. \& Croke, J. C. (1992). A genetic classification of floodplains. Geomorphology, 4 (6), 459-486. 


\title{
A genetic classification of floodplains
}

\section{G.C. Nanson and J.C. Croke}

Department of Geography, University of Wollongong, Wollongong, N.S. W 2500, Australia

\begin{abstract}
Floodplains are formed by a complex interaction of fluvial processes but their character and evolution is essentially the product of stream power and sediment character. The relation between a stream's ability to entrain and transport sediment and the erosional resistance of floodplain alluvium that forms the channel boundary provides the basis for a genetic classification of floodplains. Three classes are recognised: (1) high-energy non-cohesive; (2) medium-energy non-cohesive; and (3) low-energy cohesive floodplains. Thirteen derivative orders and suborders, ranging from confined, coarse-grained, non-cohesive floodplains in high-energy environments to unconfined fine-grained cohesive floodplains in low-energy environments, are defined on the basis of nine factors (mostly floodplain forming processes). These factors result in distinctive geomorphological features (such as scroll bars or extensive backswamps) that distinguish each floodplain type in terms of genesis and resulting morphology. Finally, it is proposed that, because floodplains are derivatives of the parent stream system, substantial environmental change will result in the predictable transformation of one floodplain type to another over time.
\end{abstract}

\section{Introduction}

An alluvial channel adjusts its hydraulic geometry and builds a surrounding floodplain in such a way as to produce a stable conduit for the transport of water and sediment. The active boundary of the channel is usually where the floodplain is being constructed or eroded although during large floods this activity can extend across much of the floodplain surface.

As early as Dana (1863, pp. 555-556), Lyell (1867, pp. 443-444), and most particularly Gilbert's (1877, pp. 126-127) work in the Henry Mountains of Utah, geomorphologists have recognised the genetic association between rivers and the floodplains they construct. This interdependence is adopted here as the basis for a comprehensive floodplain classification. 
In the past the literature on floodplains was dominated by a few case studies of very specific types, for example, the floodplains of the Mississippi (Fisk, 1944, 1947), Watts Branch (Wolman and Leopold, 1957), the Klaralven (Sundborg, 1956) and the Brahmaputra (Coleman, 1969) which tended to be over-emphasised in terms of their importance. More recent research suggests that the range of processes involved in floodplain formation is now so large, and the variety of floodplain types so diverse, that almost every case study might be seen to require a new model (as has been observed for sedimentary facies models by Dott and Bourgeois, 1983, and Miall, 1985, 1987). There is clearly a need, therefore, to assimilate the full range of floodplain types into a contemporary review.

In a recent study, Nanson (1986) argued that floodplains reflect a landform continuum through many styles from highto low-energy environments. Alluvial river channels can be differentiated on the basis of particular force-resistance relationships (Brotherton, 1979; Ferguson, 1981, 1987; Richards, 1982; Carson, 1984; Graf, 1984), therefore, by association the floodplain should reflect a balance between the stream's ability to do work (i.e. stream power), or more specifically, to entrain and transport sediment (i.e. shear stress) and the resistance of the channel boundary to erosion. Additionally, the amount and texture of the sediment load is seen to be very important in determining channel and floodplain geomorphology (Schumm and Khan, 1972; Carson, 1984) for both are closely related to stream power (Bagnold, 1966). Ripirian vegetation (Smith, 1976; Hickin, 1984), human interference and a variety of inherited antecedent conditions (Wilcock, 1967; Ferguson, 1981; Brown, 1990; Croke, 1991 ) also affect channel processes and hence floodplain development; however, these variables are difficult to assess on the basis of the available information and as a consequence are not included in this analysis. Also not considered are mass-movement (e.g. Lattman, 1960) and aeolian processes that contribute to floodplain formation in particular environments.

The purpose of this paper is twofold; firstly to review observations on the formation of floodplains and secondly, to develop a classification that highlights both the distinctiveness and interconnectedness of these complex landforms. The classification presented here is an energy-based systematic ordering of floodplains of varying morphological and sedimentary character. In theory, the sequence can occur in any single drainage basin from source to mouth but it is likely to be only partially represented along an individual river and not necessarily in an entirely predictable downstream pattern. The classification recognises three floodplain classes (based on stream power and sediment characteristics) and a combination of thirteen floodplain orders and suborders (based on primary and secondary factors, largely geomorphic processes). 


\section{Floodplain definition}

The existence of a diverse and ambiguous floodplain terminology presents an obstacle to their classification (Kellerhals et al., 1976; Miall, 1975, 1985; Lewin, 1978; Graf, 1988). Hydrologists and engineers define the floodplain as the surface next to the channel that is inundated once during a given return period regardless of whether this surface is alluvial or not (Hydraulic Engineering Centre, 1976; Ward, 1978). This we term the hydraulic floodplain, for geomorphic history does not play a role in its definition (Graf, 1988). The genetic floodplain we define as the largely horizontally-bedded alluvial landform adjacent to a channel, separated from the channel by banks, and built of sediment transported by the present flow-regime. This is a landform contemporaneous with present hydroclimatic conditions.

Over a period of decades or even centuries, only a small fraction of the total alluvium in a river valley is transported by the river; the bulk is stored in contemporary floodplains or in ancient alluvial deposits. Floodplains formed under prior flow regimes are often assumed to be recognisable as river terraces, yet in reality the separation of contemporary and ancient alluvia is more complex than this (see Brakenridge, 1987). Floodplains usually form over considerable periods of time and frequently reflect processes that are time transgressive. Along a laterally stable or slowly migrating river, the basal or distal parts of the floodplain may be a legacy of a prior flow regime while the upper units or those proximal to the channel are most likely to represent sediment transported and deposited by the present flow regime. What results is a polyphase floodplain, the product of secular climate or other environmental (e.g. base level or land use) change. Where antecedent factors prevail, persistent passive disequilibrium (Ferguson, 1981) floodplains relate closely to the controls of past hydrological and sedimentological regimes (Froelich et al., 1977; MycielskaDowgiallo, 1977; Brown, 1990; Croke, 1991). The classification presented here is primarily concerned with genetic floodplains which, although they may contain elements from prior flow regimes, have been dominantly formed or reformed by contemporary processes.

In certain environments, climate and hydrology can oscillate widely about a mean condition over periods of decades (Dury, 1982; Erskine and Bell, 1982), with important consequences for geomorphic processes (Warner, 1987; Erskine and Warner, 1988). Such changes are not evidence of secular climate change but are normal multidecadal variations in weather patterns such as those induced by the forcing effects of the El Niño-Southern Oscillation; they are regarded here as part of the present flow regime. Nanson and Erskine (1988) show that a variety of equilibrium and 
disequilibrium models explain contemporary channel and floodplain change along the coastal streams of southeastern Australia. Dynamic sand-bed rivers can exhibit a morphology which oscillates in a cyclical equilibrium fashion between two alternate states in response to relatively short-term periods of several decades dominated alternatively by floods or droughts. Less responsive gravel-bed rivers, or those in confining bedrock valleys, undergo much less frequent catastrophic change. Nanson (1986) termed these active disequilibrium floodplains; they erode by vertical and lateral stripping during high-magnitude, low-frequency events and gradually accrete again during the intervening periods of less extreme conditions. Brakenridge (1987) also relates the differences in floodplain sedimentation and stratigraphy within certain river systems in the United States and central Europe to the effects of frequent and infrequent flow events.

\section{Floodplain depositional processes}

Following the work of Gilbert (1877), Russell (1898), Fenneman (1906), Mackin (1936) and Wolman and Leopold (1957), there was a widely held view that floodplains were formed almost entirely of lateral accretion deposits (Allen, 1965; Douglas, 1977; Ritter, 1978). Wolman and Leopold's observation of remarkably constant overbank floodrecurrence intervals along a wide variety of rivers, as well as measurements taken of vertical accretion immediately after floods, suggested that overbank deposition is relatively insignificant (see also Bridge and Leeder, 1979). However, emerging from more recent studies is the realisation that lateral accretion is not necessarily the dominant mechanism of floodplain formation in every environment and point bars are not always the primary sedimentary landform in their development (Jackson, 1978; Lewin, 1983; Brakenridge, 1987). From a review of the literature and additional field evidence, three main processes of floodplain formation can be recognised: (1) lateral point-bar accretion; (2) overbank vertical-accretion; and (3) braid-channel accretion. Three less common processes are (4) oblique accretion; (5) counterpoint accretion, and (6) abandoned-channel accretion. All six processes operate singly or in combination to produce a variety of floodplain types.

(1) Lateral point-bar accretion results from the progressive deposition of point bars on the convex bank of a meander bend as the result of helical and divergent flow and a complex pattern of shear stress distribution within the bend (e.g. Dietrich, 1987). Progressive erosion of the cut bank and accretion of the opposite point bar causes the channel to migrate, creating in its wake a new floodplain of juxtaposed point-bar deposits capped with overbank sediment (Sundborg, 1956; Leopold and Wolman, 1957; Jackson, 1976; Ritter et al., 1973; and Nanson, 1980). A variety of floodplain morphologies can result, some with little surface relief and others with well developed scroll patterns. 
(2) Overbank vertical-accretion results from the overbank deposition of sediment during floods. It has been shown to be the dominant process along certain low-gradient single-thread channels (Beckinsale and Richardson, 1964; Schumm, 1968; Ritter et al., 1973; Rose et al., 1980; Nanson and Young, 1981; Burrin and Scaife, 1984; Burrin, 1985) and anastomosing channels (Smith, 1972, 1974; Smith and Smith, 1980) where there is insufficient stream power to permit channel migration. The most active vertical accretion environments occur along high-energy channels with sandy floodplains that can be destroyed catastrophically by large floods and subsequently reconstructed predominantly by overbank deposition (Schumm and Lichty, 1963; Burkham, 1972; Nanson, 1986). Levees, crevasse splays and backswamp deposits are very important styles of deposition and have been described in detail elsewhere (e.g. Happ et al., 1940; Coleman, 1969), but in this broad classification they are considered generally overbank in nature and are not discussed separately.

(3) Braid-channel accretion is the product of a combination of processes including: (i) the shifting of primary braid channels to another part of the valley allowing the stabilisation of previously active areas of braid bars and river bed (Rust, 1972); (ii) local aggradation and later channel incision resulting in the formation of abandoned braid-bars as partly erosional, elevated features (Smith, 1971; Bluck, 1974; Carson and Griffiths, 1989); (iii) the formation of extensive, elevated bars during a large flood forming a stable surface beyond the reach of regular flood events. These combine to form a mosaic of deposits along braided rivers (Leopold and Wolman, 1957; Doeglas, 1962; Fahnstock, 1963).

(4) Oblique accretion has been observed by the authors causing extensive alluviation along some Australian meandering streams and have been described as inner accretionary bank deposits on the River Endrick in Scotland (Bluck, 1971). These occur as muddy drapes which are lapped on to the relatively steep convex banks of certain channels and contrast with the distinctive bar topography and relatively coarse texture of point-bar deposits. It is possible that, in a limited number of environments, particularly those with high suspended-load concentrations, oblique accretion in combination with slow rates of lateral migration provides the dominant mechanism of floodplain formation.

(5) Counterpoint accretion occurs within a separation zone formed against the upstream limb of the convex bank of tightly curving bends (Carey, 1969; Woodyer, 1975; Hickin, 1979; Thome and Lewin, 1979; Lewin, 1983; Page and 
Nanson, 1982). These deposits, laid down as a within-channel bench in this slack-water area, contain a high proportion of suspended sediment with organics, making a notable contrast to the much coarser point-bar sediments they adjoin (Nanson and Page, 1983). It should be noted that Smith (1987) has described gravel counterpoint bars on a meandering gravel-bed river in Wales; just how they relate to the above fine-grained type is unclear and will await further investigation.

(6) Abandoned-channel accretion is characteristic of a relatively small proportion of the total area of most river floodplains, including braided-river floodplains, although they have been shown to represent up to about $20 \%$ of the area of actively-migrating river floodplains with frequent cuttoffs (Lewis and Lewin, 1983; Lewin, 1983). They are usually fine-grained swampy or lacustrine sediments in the upper part while grading to channel sands or gravels near the base (Page and Mowbray, 1982), their architecture reflecting the morphology of the original channel.

It could be implied that island formation is a discrete process but here islands are viewed as the product of composite processes such as lateral point-bar accretion, overbank vertical accretion, etc. As research continues into particular depositional environments it will become possible to add to and refine this list of floodplain processes as has been done for overbank deposition by Farrell (1987).

\section{Floodplain classifications}

Despite a substantial number of individual case studies over the past decade, there has been no attempt at a comprehensive classification of floodplains. In contrast, considerable attention has been given to the classification of natural channel patterns focussing on planimetric or process-based criteria (e.g. Leopold and Wolman, 1957; Popov, 1964; Schumm, 1968; Brotherton, 1979; Ferguson, 1981, 1987; Carson, 1984). Two relatively recent and widely used textbooks in fluvial geomorphology (Richards, 1982; Knighton, 1984) do not attempt to classify floodplains, although that by Petts and Foster (1985) categorises them into three basic types; those formed by meandering, braiding and anastomosing rivers. From a review of the few studies which have attempted to categorise floodplains, it appears that there are essentially three types of classification: morphological, specific and genetic.

(1) Morphological: This approach is concerned with the description of discrete floodplain landforms and accompanying river patterns (e.g. Thornbury, 1969; Petts and Foster, 1985) and is based largely on work initiated on the Mississippi and its tributaries (Happ et al., 1940; Fisk, 1944, 1947; Schmudde, 1963). Reviews by Allen (1965) 
and Lewin (1978) represent summary descriptions of floodplain landforms but they are not floodplain classifications per se. While a morphological classification can be constructed (Lewin, 1978), each floodplain category becomes the sum of its landform components and the classification is not one in which form and process are closely linked.

(2) Specific: Specific classifications refer primarily to riverscape inventories which have been constructed for engineering purposes (Kellerhals et al., 1972; Galay et al., 1973) and for water resource, recreational and biological assessment of rivers and floodplains (Moseley, 1987). They contain a great deal of tabulated information about whole reaches of rivers and, while not intended as floodplain classifications, they are useful to those concerned with river design and floodplain management. However, this type of inventory contains no dominant or unifying variable and the result can be a rather inelegant compendium of data similar to a land inventory. In a successful example, Mollard (1973) listed 17 questions commonly asked of geomorphologists by engineers constructing river projects. He then developed a classification of channel patterns from aerial photographs that, because it relates each class to river process, can also be regarded as a genetic or process-based classification of channels and floodplains.

(3) Genetic: This approach was implicit in the earliest floodplain descriptions of Gilbert (1877), Russell (1889) and Fenneman (1906). Melton (1936) later took Fenneman's deductions on the relative importance of overbank deposition and applied them to the first genetic classification of rivers and river floodplains but he failed to provide any detailed stratigraphic, sedimentological or hydraulic evidence on which to base his various types. In general, four geomorphic parameters are used, either singly or in combination, as criteria in genetic classifications: channel pattern (Leopold and Wolman, 1957; Speight, 1965; Schumm, 1968, 1977; Petts and Foster 1985); lateral stability (Kellerhals et al., 1976; Lewin, 1978); morphological landform description (Allen, 1965; Butzer, 1976; Lewin, 1978); and sedimentary characteristics (Allen, 1965; Jackson, 1978; Leeder, 1978; Galloway, 1981).

From a geomorphic perspective, floodplains are best categorised genetically because of the interrelation between river processes and the floodplains they construct. Such a classification should permit a maximum level of information storage, interpretation and explanation. However, because of the multivariate and interactive nature of the fluvial processes and landforms involved, such classifications are inherently difficult to formulate. For example, a simple association between sedimentation pattern and channel planform is now recognised to be erroneous (Jackson, 1978; Lewin, 1983; Bridge, 1985; Brierley and Hickin, 1991) because sedimentation processes are not uniquely associated with specific river-planform types. There is, therefore, a need to move away from simplistic models to ones which 
allow the diversity of fluvial processes and floodplain types to be recognised (Jackson, 1978; Burrin, 1985; Miall, 1985).

\section{An energy-based floodplain classification}

While the classification of such complex systems as floodplains cannot be based entirely on a single variable, shear stress offers the possibility of providing the basic organising principle, and it is largely scale independent. It is a measure of a stream's competence and reflects turbulence intensity, and hence defines the streams ability to transport sediment as traction load or suspended load. These two transport mechanisms are highly discriminatory in terms of the construction of different floodplain types. Ferguson and Ashworth (1991) predict channel changes along a Scottish stream on the basis of changes in shear stress. However, a serious limitation of using shear stress as the primary discriminating variable in this classification is that very few floodplain studies have provided sufficient hydraulic data from which to calculate shear stress, the most notable absence being details of flow depth or hydraulic radius.

Closely related to shear stress is specific stream-power (Bull, 1979) which is somewhat more scale dependent as it contains both the depth and velocity terms. However, it appears that some floodplain types are determined, in part, by the size of river. For example, cut and fill floodplains (see below) appear to be associated only with small streams whereas braided river floodplains are very commonly associated with large wide rivers (despite analogues being produced in small laboratory flumes). Like shear stress, stream power is a useful predictor of boundary erosion and channel migration (Hickin and Nanson, 1984; Nanson and Hickin, 1986), sediment transport (Bagnold, 1966, 1977), sediment deposition and bedform type (Simons et al., 1965), and it is largely these that determine the geomorphology of the channel and floodplain. Aspects of channel morphology have previously been explained in terms of the availability of gross or specific stream power (see below) (Bull, 1979; Ferguson, 1981, 1987; Richards, 1982; Carson, 1984). Ferguson $(1981,1987)$, for example, identified a relation between channel pattern and specific stream-power but it is poorly defined because of interfering factors such as bank strength and sediment supply.

Because stream power is diagnostic of flow and sediment properties, the erosive power/resistance concept is employed here as the primary basis for organising river floodplains into classes. Many studies provide slope and flood-discharge data from which gross stream-power can be calculated, and by measuring channel widths from included maps and diagrams, specific stream power can be determined. The use of additional geomorphic factors provides a second level of discrimination (into orders and suborders) and allows the classification to reflect a more complete hierarchy of 
floodplain forms and processes. It must be recognised, however, that there is always an element of subjectivity in the subdivision and classification of overlapping and continuously varying phenomena. For example, implicit in the widely accepted quadrapartite division of rivers into straight, meandering, braided and anastomosing is the recognition that these classes are not mutually exclusive and hence not all channels fall neatly into them. While few would dispute that this subdivision of river types has been pedagogically very useful and has helped to focus research, it is accepted that all classifications are human contrivances; they are simplifications of reality.

Available stream power or rate of doing work per unit length of channel, defined as gross stream-power is summarised by:

$\Omega=\gamma Q S$

where $y$ is the specific weight of water, $Q$ is the discharge and $\mathrm{S}$ the slope (Bagnold, 1966). While gross stream-power is a useful measure of the total energy and total work done by the river at any point along its length, it is power per unit wetted perimeter of the channel (usually expressed as per unit channel width) that is diagnostic of the power available to erode and construct individual landforms within the system. This is termed specific stream power (Bull, 1979) and is summarised by:

$\varpi=\Omega / W$

where $W$ is width.

In this study, specific stream power is calculated for bankfull flow conditions. An important limitation in using any measure of channel hydraulics is that it relates to within-channel processes in a classification that should also emphasise on-the-floodplain processes. However, it is impossible to obtain quantitative estimates of the latter from the published literature. It has, therefore, been necessary to assume that the intensity of within-channel and on-thefloodplain processes are reasonably closely correlated within the range of energy environments considered here.

Three categories of specific stream power, expressed qualitatively as high, medium and low, are used to differentiate floodplain energy conditions within the classification. This tripartite division of stream power incorporates the concept of spatially divisible "zones" within the continuum of a river's course (Schumm, 1968; Pickup, 1984, 1986) and implies, indirectly, a corresponding decrease in the calibre of stream load. The calibre of the sediment load determines 
the sedimentary composition of the floodplain which in turn strongly influences the resistance of the stream banks to erosion (Hickin and Nanson, 1984).

Despite the recognised importance of boundary resistance in determining channel and floodplain form (Schumm, 1968; Ferguson, 1981, 1987; Richards, 1982; Knighton, 1984, 1987), as yet there is no consistent, quantitative method available for the measurement of the erosional resistance of stream banks at a variety of discharges within a range of geomorphic and vegetative environments. However, it is well known that sediment entrainment is a complex (nonlinear) function of sediment size (Hjulstrum, 1935; Shields, 1935), while channel migration rates (floodplain erosionrates) are largely a product of the Shields entrainment function in bends of uniform curvature (Hickin and Nanson, 1984).

In this classification, floodplains are initially divided into two groups similar to those proposed by Knighton (1984) for river channels: those floodplains comprised largely of non-cohesive alluvium (gravel to find sand); and those of cohesive alluvium (silt and clay). Because of the almost direct relationship between sediment size and entrainment threshold in the continuum of non-cohesive sediments, such floodplains are divided here into two energy environments; high and medium (it is impracticable to attempt a finer subdivision until more studies have been carried out on floodplains in a range of energy environments). As silt and clay show an inverse relationship between erodibility and sediment size, and because they only occur extensively in floodplains of low-energy environments, a third class of low-energy cohesive floodplains is recognised. This tripartite division into classes within the classification, generalised as it is, reflects the interrelation between a stream's ability to do work (as estimated using specific stream-power) and the erosional resistance of the floodplain (as estimated from sediment size). 


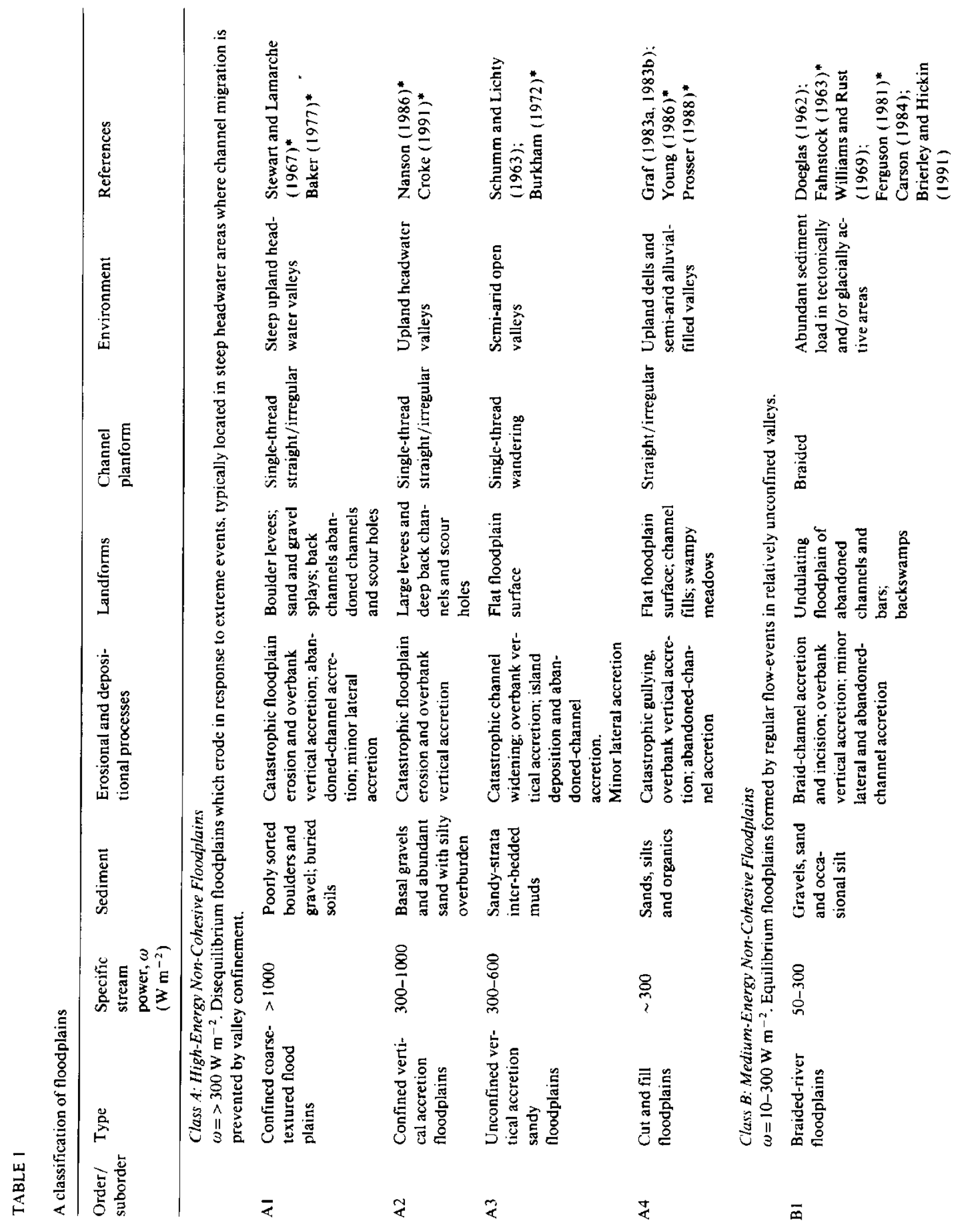




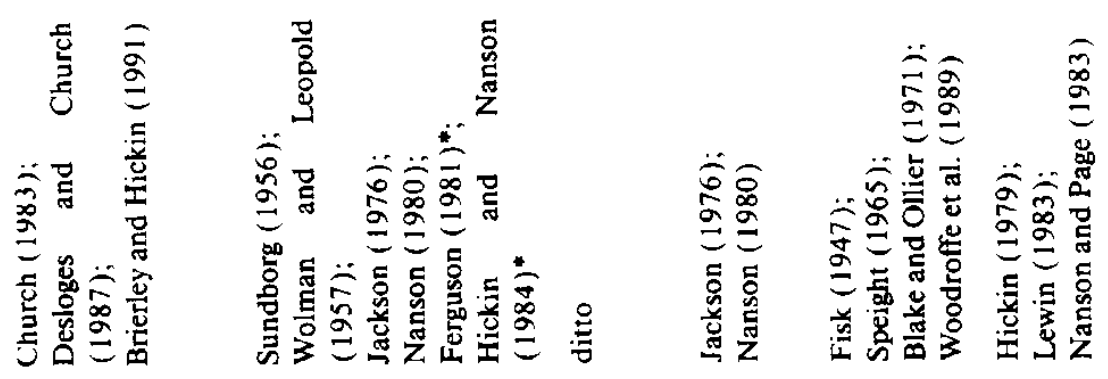

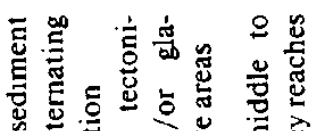

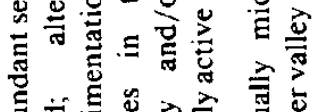

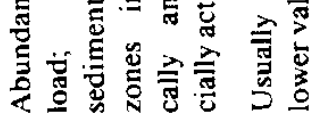

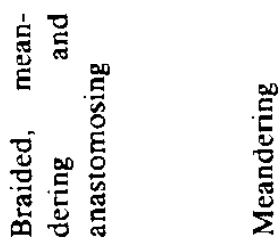

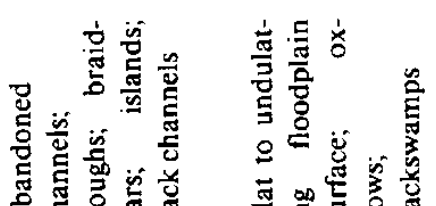

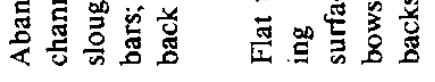

荳

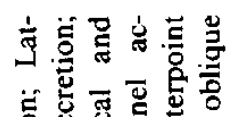

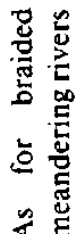

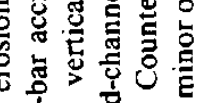

善 言

高

产

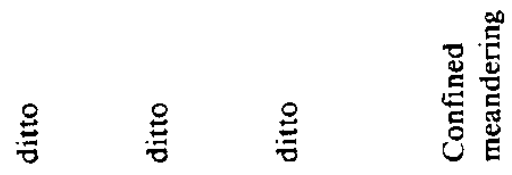

离

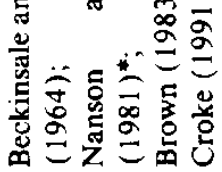

$\frac{d}{\bar{z}}$

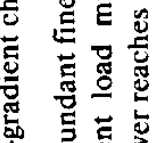

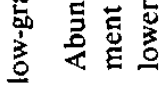

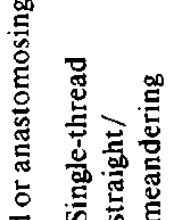

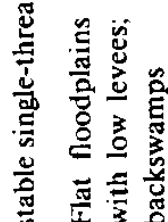

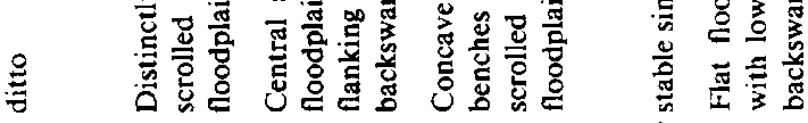

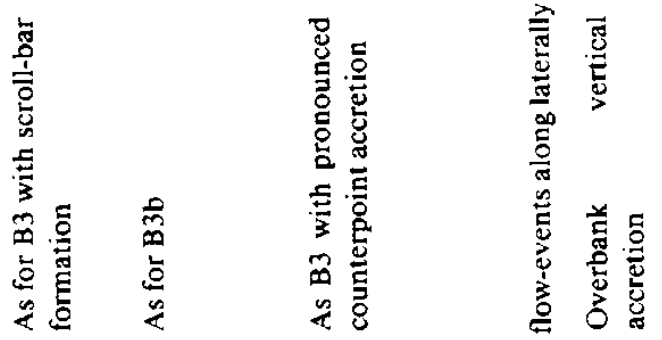

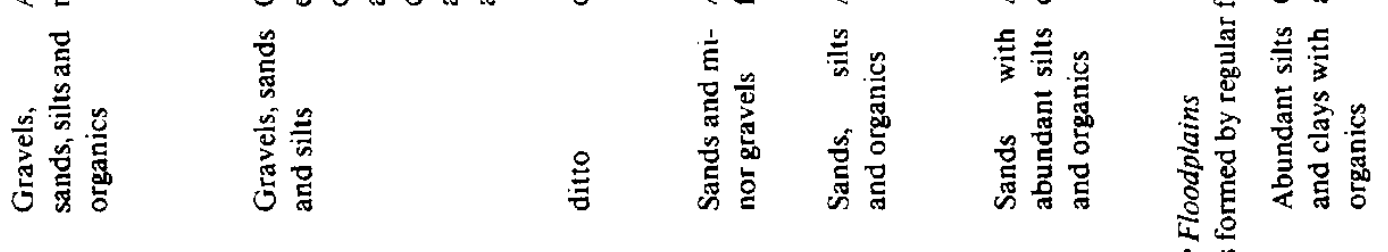

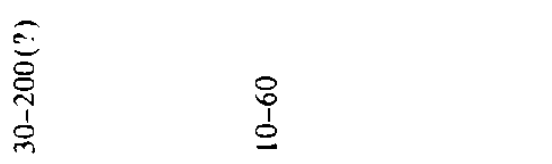

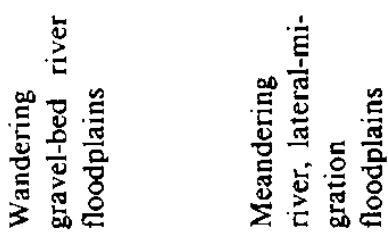

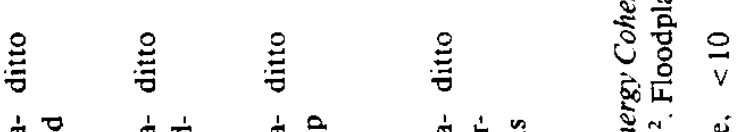

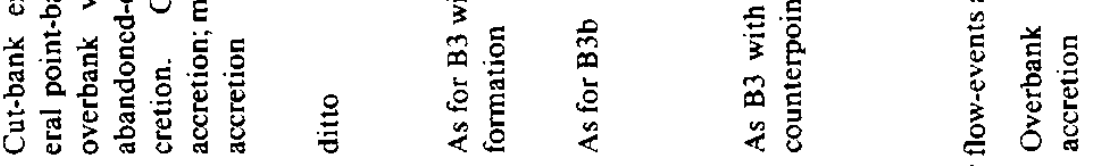

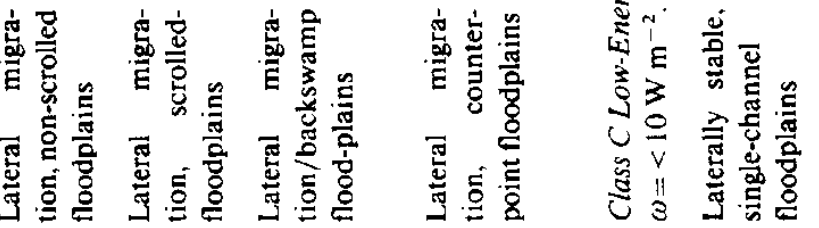

มี

9

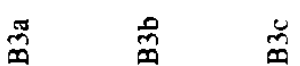

$\ddot{D}$

ฮ 


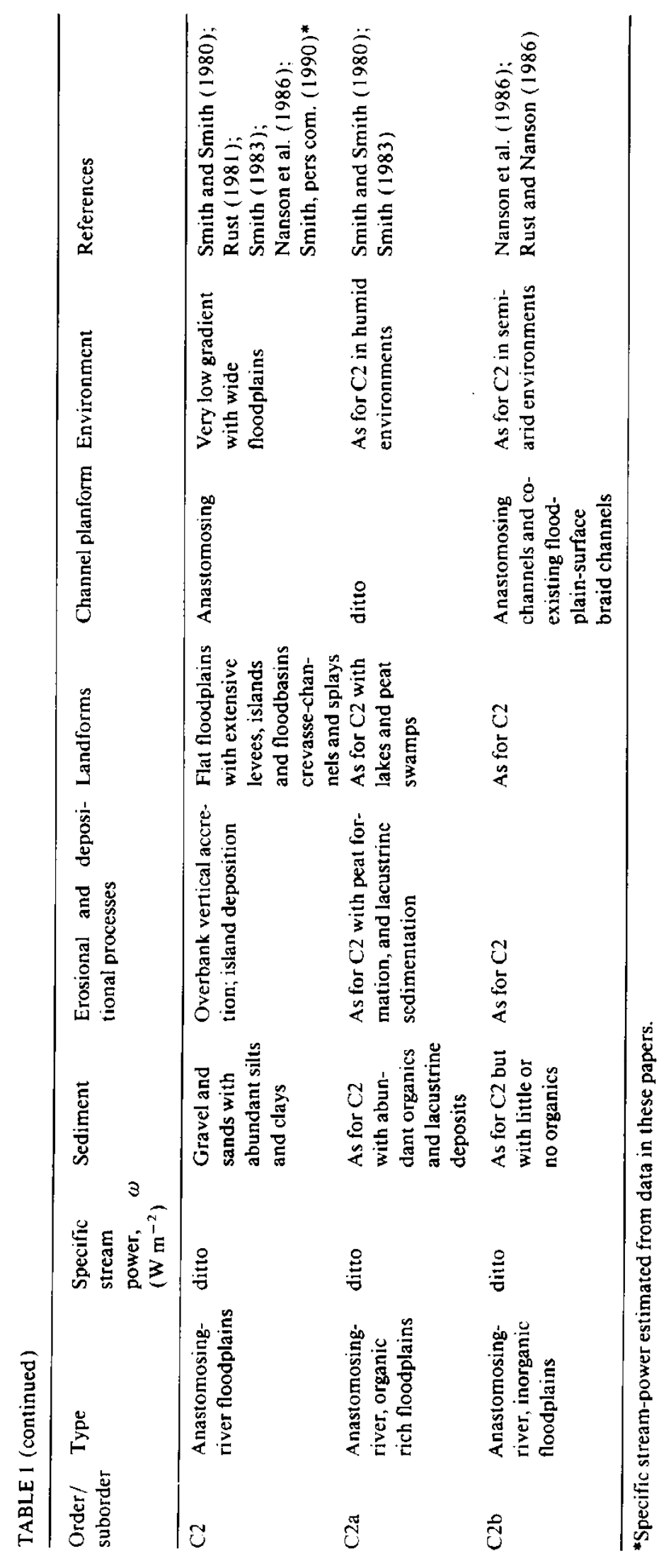


Class A. High-energy non-cohesive floodplains (Specific stream power at bankfull: $>300 \mathrm{~W} \mathrm{~m}^{-2}$ ). These are disequilibrium landforms which erode, either completely or partially, as a result of infrequent extreme events. In some cases floodplains which are close to some threshold condition may erode as a result of a series of moderate events. Stream power is typically high because of their location within steep upland areas and bank erodibility is primarily a function of the linear relation between the size of sediment entrained and stream power. Despite their high energy, these channels are usually prevented from migrating laterally by very coarse alluvium or bedrock and their floodplains are dominated by relatively coarse vertical-accretion deposits.

Class B. Medium-energy non-cohesive floodplains (specific stream power at bankfull: 10-300 $\mathrm{W} \mathrm{m}^{-2}$ ). These floodplains are considered to be in dynamic equilibrium with the annual to decadal flow regime of the channel and are not usually affected by extreme events; specific stream powers are kept at a medium level because large floods spill overbank and disperse their energy across extensive floodplains. As with Class A above, bank erodibility is essentially a direct function of sediment texture. The preferred mechanism of floodplain construction is by lateral point-bar accretion or braid-channel accretion.

Class C. Low-energy cohesive floodplains (specific stream power at bankfull: $<10 \mathrm{~W} \mathrm{~m}^{-2}$ ). These floodplains are usually associated with laterally stable single-thread or anastomosing channels; low stream power is primarily a function of their small channel size and/or their very low slope, and as with Class B above, the floodwaters readily spill overbank dissipating erosional energy. Bank resistance is high because of their fine-grained cohesive composition which inhibits lateral migration. These floodplains are formed pre-dominantly by vertical accretion of fine-grained deposits and by infrequent channel avulsion.

\section{Floodplain orders and suborders}

Nine discriminatory geomorphic factors (mostly fluvial processes) provide a second and sometimes third level of floodplain differentiation into floodplain orders and suborders. These factors are: (1) valley confinement; (2) channel cutting and filling; (3) braid-channel accretion; (4) lateral point-bar accretion; (5) overbank vertical-accretion; (6) anabranching; (7) scroll-bar formation; (8) counterpoint accretion; and (9) organic accumulation. The first six are primary factors that differentiate floodplains into orders whereas the remaining three are secondary factors that differentiate floodplains into suborders. 
In this list of nine factors, lateral point-bar, overbank vertical, braid-channel and counterpoint accretion are four of the six floodplain depositional processes described earlier; channel cutting and filling is heavily dominated by the floodplain depositional process of abandoned-channel accretion. Oblique accretion, while described earlier as a floodplain process, is not emphasised here as a discriminatory factor because, to date, it has not been widely observed, nor has it been seen to result in a morphologically distinct floodplain type. Anabranching is a complex channel process that is poorly understood but results in very distinctive channel and floodplain systems (Smith and Smith, 1980). Scroll-bar formation results from the vertical accretion of floodplain sediments superimposed on an initial ridge on the point-bar and produces a very distinctive floodplain type along certain meandering rivers (Jackson, 1976; Nanson, 1980).

Unlike the eight other factors, valley confinement is not a process. It is an independent external variable that can have a profound impact on floodplain character by restricting channel migration; channel bends can become fixed in position by bedrock obstructions resulting in a dominance of overbank sedimentation and the construction of large levee banks (Nanson, 1986). In unconfined situations, and given sufficient power, channels are free to migrate and to build floodplains by a variety of processes. A clear distinction is made in Class A between confined and unconfined floodplains.

These eight factors are not mutually exclusive within any floodplain and, with the exception of valley confinement, are all to some extent dependent on stream power and sediment load. However, they do identify distinctly different environments and conditions for floodplain formation and consequently permit the differentiation of floodplain types. These details along with estimates of specific streampower, obtained where possible largely from the published literature, are presented in Table 1.

\section{Class A. High-energy non-cohesive floodplains}

These floodplains are illustrated in Fig. 1.

Order A1. Confined coarse-textured floodplains

These floodplains are typically found in steep confining bedrock valleys and narrow gorges which experience highenergy flash flooding resulting in catastrophic erosion and the transportation of very coarse sediment (Fig. 1i). They are formed largely of poorly sorted gravel and boulders with some sand and buried soils. Their uneven surfaces consist 
commonly of large coarse-grained levees, sand and gravel splays, chute and transverse bars, scour holes and abandoned channels, usually covered with a thin overbank deposit of fine alluvium. There are numerous examples of confined coarse-textured floodplains in the literature although it is usually their flood characteristics rather than their floodplains that are the primary object of investigation (e.g. Anderson and Claver, 1977, 1980; Carling, 1986). Steep gradients and confining valleys enhance the effects of high-magnitude, low-frequency floods. Croke (1991) described many of these features as characteristic of confined upland headwater floodplains in southeast Ireland. In a detailed study of the effects of a 100 yr flood in a Californian mountain valley, Stewart and Lamarche (1967) describe the erosion and deposition that resulted, specifically noting that the mechanism of floodplain formation is significantly different to the accepted model by Wolman and Leopold (1957). Channel banks and levees are formed of very coarse sediment such that lateral migration is only possible during extreme events. The floodplain forms from a combination of lateral, vertical and abandoned-channel accretion. In some cases levees continue to grow and attain heights that retain flow within the channel except during the largest floods; overbank deposition thereby becomes very infrequent. However, in narrow very active gorges the floodplains may be frequently reworked and become almost ephemeral in character. During particularly high-magnitude events channel avulsion can tear the existing floodplain apart and replace it with channel and overbank deposits of coarse sediment, even at locations far removed from the pre-flood channel.

In a study of flood events in a semi-arid, hilly region of central Texas, Baker (1977) describes valley fills that are deeply scoured and redeposited during extreme events capable of entraining jointed bedrock and boulders up to $3 \mathrm{~m}$ in diameter. Chute scouring and deposition of gravel bars and ridges, particularly across meander bends, reworked the floodplains but in Baker's study flow depths and velocities appear to have been too great for the formation of pronounced levees.

\section{Order A2. Confined vertical-accretion sandy floodplains}

Confined vertical-accretion sandy floodplains are formed largely of sand but with basal gravels and are characterised by well defined levee banks and deep back channels (Fig. 1ii). They typically build in lower energy environments that those of Order A1. The main channel is laterally stable due to partial constriction in a confining bedrock valley which also acts to concentrate the erosional power of extreme flood events. Overbank deposition gradually builds a floodplain of sandy-silty alluvium over a period of hundreds or thousands of years, following which catastrophic 
erosion by a single large flood, or a series of more moderate floods, strips the floodplain to a basal lag deposit from which it slowly reforms (Nanson, 1986). This periodic destruction appears due to the progressive development of large sandy levee banks and floodplain surfaces of highly variable relief. Such relatively weak, unstable, sandy floodplains may survive over extended periods of time because the channel bends are restrained by bedrock valleysides. Croke (1991) also describes this process of floodplain stripping across confined meander bends and floodplain reconstruction by sandy overbank vertical accretion deposits which contain distinct cobble lenses indicative of the high transport power. The long-term effect in many cases is a floodplain that is almost perpetually in a state of disequilibrium. It is either gradually building by vertical accretion and, therefore, deepening its channel while slowly increasing specific stream-power, or it is severely eroding and thereby rapidly decreasing its specific power across a wider channel cross-section.

\section{i) Confined Coarse-Textured Floodplain $\omega=>1000 \mathrm{Wm}^{-2}$}
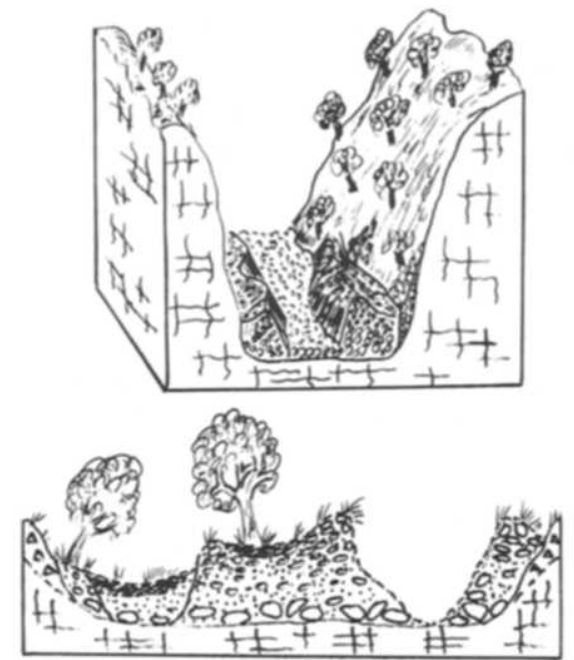

iii) Cut and Fill Floodplain $\omega=\sim 300 \mathrm{Wm}^{-2}$
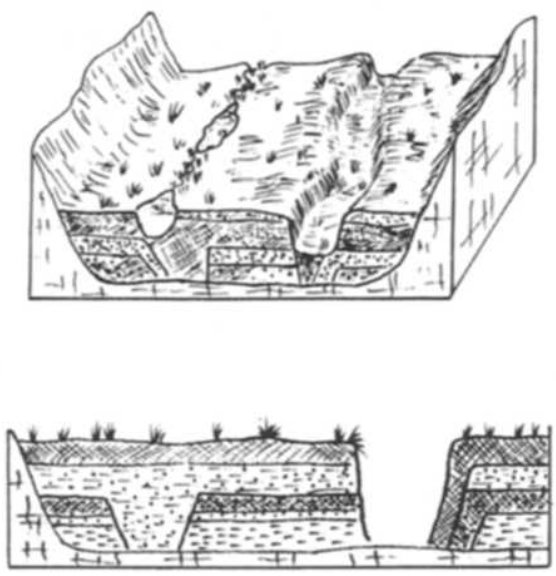

ii) Confined Vertical-Accretion

Sandy Floodplain $\omega=300-1000 \mathrm{Wm}^{-2}$
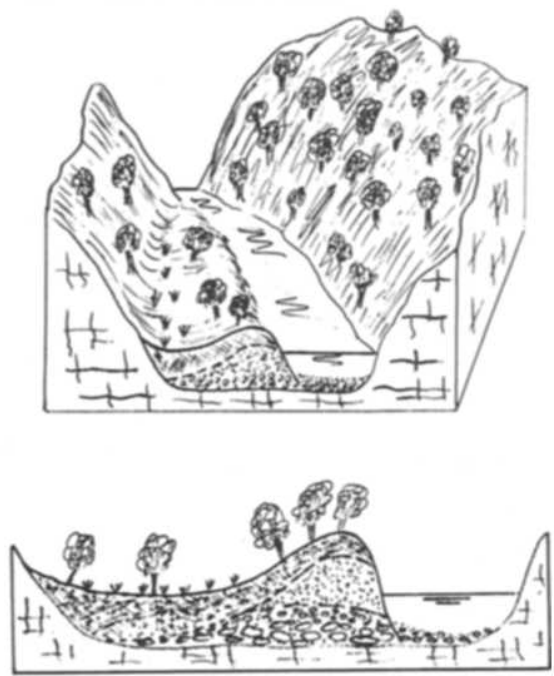
Fig. 1. High energy non-cohesive floodplains. (i) Confined coarse-textured floodplain (after Stewart and Lamarche, 1967 and Baker, 1977). (ii) Confined vertical-accretion sandy floodplain (after Nanson, 1986). (iii) Cut and fill floodplain (after Prosser, 1988).

Order A3. Unconfined vertical-accretion sandy floodplains

Unconfined vertical-accretion sandy floodplains have been described in arid and semi-arid regions of the United States by Schumm and Lichty (1963) and Burkham (1972). Unfortunately, the illustrations of these floodplains in the above two papers are not sufficiently detailed to allow us to create a representative diagram in Fig. 1.

Unlike Order A2, the channel is not constrained by a bedrock valley and does not have large levees. While the regional environment in which they form is similar to the arroyo type described below, these floodplains are much broader and are eroded by extensive channel widening not accompanied by significant incision. Overbank verticalaccretion, associated with the coalescence of islands and the infilling of abandoned channels, builds a floodplain rapidly and simultaneously over a wide area. During years of above average precipitation, interbedded sandy units with mud veneers accumulate within the enhanced floodplain vegetation; the channel may eventually meander through these vertical-accretion deposits. Erosion and associated channel widening results from extreme flooding, often during periods of below average precipitation which limit the stabilising effect of floodplain vegetation. The erosional and depositional phases of the floodplain and channel are controlled by natural climatic phases which alternate over irregular periods measurable in decades.

Variations in stream power between the eroded and non-eroded channel states are considerable in that not only does the channel widen by more than tenfold, and thereby accept a much greater proportion of total flood discharges than would otherwise pass over the floodplain, but removal of the meander pattern increases gradients by some $20 \%$ (Burkham, 1972). An absence of stratigraphic and sedimentological information on this floodplain type means that such details must remain speculative at this stage, but they likely exhibit wide sandy strata with mud drapes.

Order A4. Cut and fill floodplains 
Cut and fill floodplains have been recognised in a wide variety of environments from humid uplands in Australia (Eyles, 1977; Erskine, 1986a; Young, 1986; Prosser, 1988) and Zambia (Mackel, 1974) to the semi-arid American southwest where the channels are termed arroyos (e.g. Bryan, 1922; Schumm and Hadley, 1957; Leopold et al., 1966; Graf, 1983a). Despite their wide geographical distribution these floodplains appear to have common depositional and erosional characteristics. Similar to Order A3 above, they accumulate sediment as valley fill during periods of erosional stability, but they occupy relatively small valleys, show little surface relief and erode by gully incision rather than massive channel widening. As a result, their alluvial stratigraphy is characterised by overbank vertical accretion deposits and abandoned-channel accretion (Fig. 1iii).

In the American southwest, arroyos have been shown to undergo significant changes in stream power as they evolve over time. They alternate from being small meandering surface channels that dissipate stream power overbank to being incised flat-floored gullies (arroyos) that confine flow to the channel and thereby concentrate stream power (Graf, 1983a). While the precise cause of arroyo cutting and infilling is not understood (Graf, 1983a), they appear to be a complex-response system (Schumm, 1973, 1979) that oscillates between the two states as a function of depositional or erosional thresholds controlled by short-term (multidecadal) changes in climate and hydrology (Graf, 1983b).

Young (1986) and Prosser (1988) have described small headwater valleys (dells) in the humid uplands of southeastern Australia that are choked with swampy sandy organic sediments due to very low stream powers that are incapable of maintaining continuous channels. During this accumulation phase these swampy meadows might reasonably be classified within Class C, the low-energy cohesive floodplains with specific stream powers of $<10 \mathrm{~W} \mathrm{~m}^{-2}$. However, their upland location and relatively steep gradients can result in high stream powers concentrated in an eroding channel $\left(\sim 300 \mathrm{~W} \mathrm{~m}^{-2}\right)$ during extreme storm-events, a condition that can never be generated on any of the lowgradient Class $\mathrm{C}$ floodplains. In contrast to arroyos that are relatively frequently rejuvenated, radiocarbon dating of the Australian upland valleys suggests that dell deposits (termed swampy meadows by Prosser) are episodically flushed out by gully erosion during very infrequent and extreme storm-events. This can occur immediately following a fire that destroys the vegetation. Sediment accumulates as a result of a stabilising feedback involving: (1) the absence of a continuous channel due to insufficient stream power, (2) the retention of abundant soil-water, (3) the exclusion of trees due to high water tables, and (4) the establishment of a swampy floodplain vegetation that acts as an efficient mesh for the entrapment of further sediment. 


\section{Class B. Medium-energy non-cohesive floodplains}

These floodplains are illustrated in Fig. 2.

Order BI. Braided river floodplains

Braided rivers are characterised by an abundant silt to gravel size load, moderately steep gradients and usually easily erodible banks. While braided rivers have been thoroughly studied, their floodplains have received scant attention such that only a preliminary interpretation can be made here as to how they form. Indeed, "floodplain" is often not a term used to define the river flats adjacent to braided rivers. Wolman and Leopold (1957) describe "islands", Williams and Rust (1969) "topographic levels", Fahnestock (1963) the "valley trains", Krigstrom (1962) "sandur plateaus" and Griffiths (1979) "berms", while Davis (1898). Doeglas (1962), Miall (1977) and Lewin and Weir (1977) use the term "floodplains". Indeed, there has been a more general terminology problem with multichannel systems; anastomosingriver floodplains have been referred to as braided-river floodplains (e.g. Norseth, 1973), although the distinction between the two has now been made clear (Rust, 1978). 


\section{i) Braided River Floodplain}

$\omega=50-300 \mathrm{Wm}^{-2}$
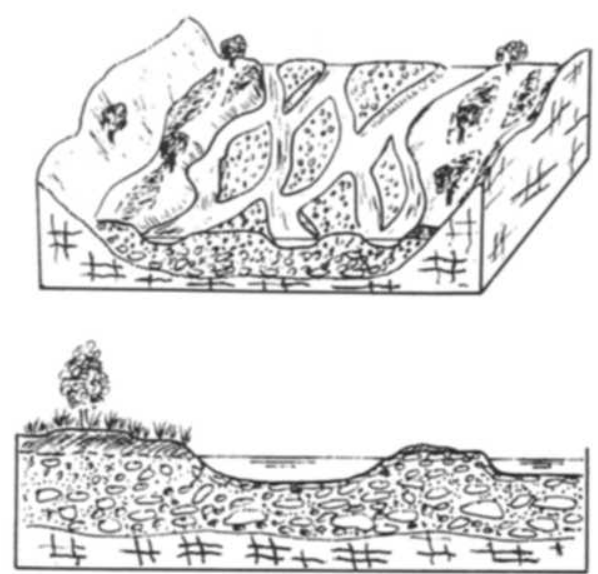

iii) Lateral Migration /

Backswamp Floodplain

$\omega=10-\ll 60 \mathrm{Wm}^{-2}$
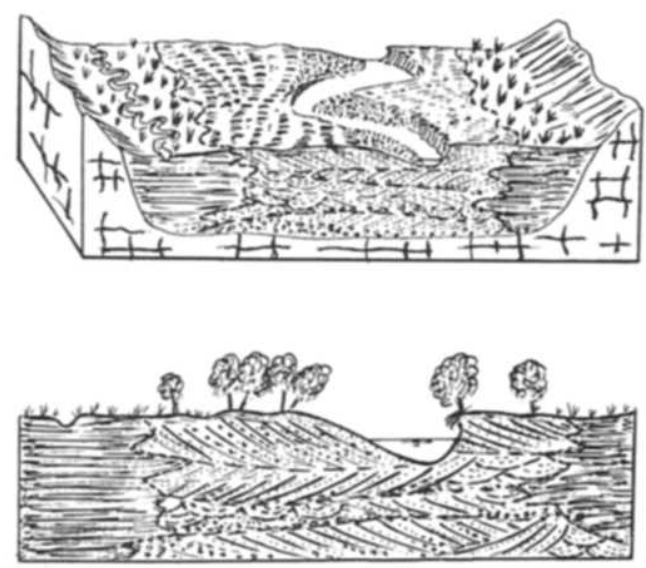

ii) Lateral Migration, Scrolled Floodplain $\omega=10-60 \mathrm{Wm}^{-2}$
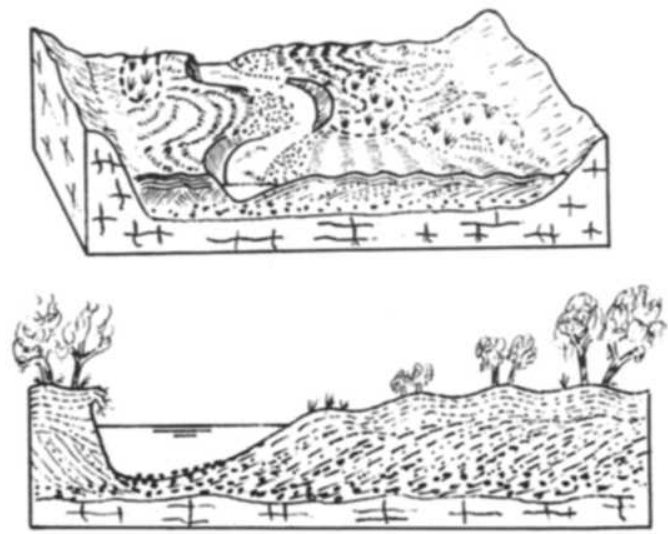

iv) Lateral Migration, Counterpoint Floodplain $\omega=10-\ll 60 \mathrm{Wm}^{-2}$
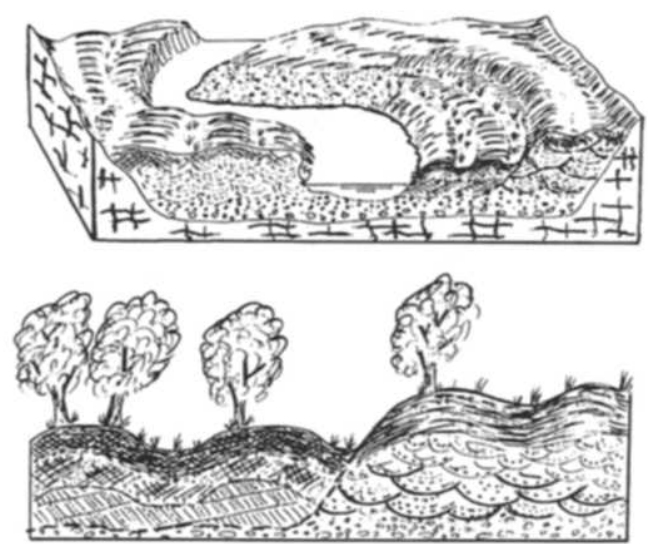

Fig. 2. Medium-energy, non-cohesive floodplains. (i) Braided river floodplain showing gravel bars and fine overbank deposition on the floodplain. (ii) Lateral-migration scrolled floodplain (after Nanson, 1980). (iii) Lateralmigration/backswamp floodplain (after Blake and Ollier, 1971 and Kesel et al. 1974). Lateral migration results in a central deposit of laterally accreted alluvium flanked by organic and fine-grained clastic overbank accretion. (iv) Lateral-migration counterpoint floodplain (after Nanson and Page, 1983). The counterpoint floodplain is forming against the concave bank of the nearest bend at a slightly lower elevation with its surface deposits finer grained and higher in organics than those on the rest of the floodplain. Flow is towards the observer.

Braided rivers can form wide valley fills although the active channels usually favour only part of the valley at any time. Because of the laterally active nature of braided rivers, their floodplains usually form in protected locations such as downstream of tributary alluvial fans or bedrock spurs (Coleman, 1969; Smith, 1974; Fahnstock and Bradley, 
1973). A general view that braided river floodplains are formed largely by the abandonment and infilling of braid channels (abandoned-channel accretion) (Carson, 1984) cannot be substantiated. Basal deposits in these floodplains represent a previously active river bed which, in the case of gravel rivers, aggrades as extensive tabular sheets, with only minor deposits of single-event unit bars (Fig. 2i) (Carson and Griffiths, 1987). In a detailed study of braided-river floodplain formation, Reinfields (1991) observed three dominant processes operating singly or in combination are responsible: (1) migration or avulsion of the primary braid channels to another part of the riverbed isolates extensive areas of accumulated alluvium and leads to floodplain stabilisation (Rust, 1972); (2) the deposition of extensive, elevated bars during a particularly large flood can produce a surface beyond the reach of lesser events, and this stabilises over time; (3) finally, localised channel incision results in the abandonment and stabilisation of adjacent bar surfaces. Once removed vertically or laterally from the proximity of active channels, these elevated surfaces accumulate overbank fines in the same way as other floodplains (Fig. 2i), although coarse splays are often incorporated.

The addition of lateral bars to the floodplain margins (Bristow, 1987) also contribute to the buildup of floodplain alluvium and on some rivers a chronological sequence of developing floodplain units is recognisable (Lewin and Weir, 1977). Reworking of the floodplain occurs as the primary channels migrate or avulse and reactivate abandoned channels (Werrity and Ferguson, 1980; Carson, 1984; Reinfields, 1991).

Floodplain facies of braided rivers usually show a finding upwards sequence (Doeglas, 1962; Williams and Rust, 1969; Miall, 1977; Brierley, 1991) from coarse channel deposits up to fine sand, silt and clay laid down as overbank sediment on a vegetated floodplain surface (Fig. 2i), however, the boundary between the coarse basal sediments and fine overburden is usually abrupt. The growth of vegetation is important for trapping and binding sediment with successionally more advanced communities located on higher topographic levels (Williams and Rust, 1969).

Indeed, there is a broad spectrum of braided-river styles that presumably produce different floodplain types, from outwash braidplains (e.g. Boothroyd and Nummedal, 1978) and Donjek-style proglacial rivers (Williams and Rust, 1969) to the Platte style (Smith, 1971). Miall (1985) outlines several of these in his architectural models and as more detailed stratigraphic information becomes available, braided-river floodplains will be divisible into different types in the same way that meandering-river floodplains are below. 
To date, wandering gravel-bed rivers have been recognised in mountainous deglaciated environments and exhibit irregularly sinuous channels with stable, well vegetated and sometimes leveed islands, anastomosing channels and braid bars. They have fewer channels and active bar platforms than in braided rivers and there is generally one dominant channel. Unstable braided or anastomosed reaches alternate with relatively stable single-channel meandering reaches, a variation apparently controlled by the local coarse sediment supply (sedimentation zones) and changes in valley gradient (Church, 1983; Desloges and Church, 1987). Floodplains develop largely by island formation associated with lateral point-bar, overbank vertical and braid-channel accretion, and by abandoned-channel accretion (Brierley, 1991; Brierley and Hickin, 1991). It is this combination of meandering, braided and anastomosing channel planform and depositional styles in the one fluvial system that makes this floodplain type distinctive, however, they are too diverse in character to easily represent in the form of a schematic diagram in Fig. 2. Lateral accretion deposits form very rapidly but are overlain by abundant vertical accretion sediments, particularly in the meandering (relatively stable) reaches and on distal parts of the floodplain whereas in braided or anastomosing (relatively unstable) reaches there are additional contributions from medial and lateral bars, attached islands, in filled avulsion channels and secondary slough deposition.

\section{Order B3. Meandering river, lateral-migration floodplains}

The migration of a meander bend results from erosion of the cutbank and concomitant growth of the opposite point bar and associated overbank deposits (Leopold and Wolman, 1957). This mechanism commonly produces a fining-upward sequence, especially in the downstream part of the bend where preservation of alluvium within the floodplain is most likely (Jackson, 1976). Variable depths of sand or gravel traction-load are deposited as part of the point-bar platform which usually fines in the downstream direction (Bluck, 1971; Jackson, 1976). On to this platform, interbedded, variably-textured alluvium accumulates, often reworked by secondary currents that move sediment towards the convex bank (Allen, 1970; Jackson, 1976). Considerable fine-grained suspended sediment can also be deposited on the point bar in the form of within-channel deposits which are often difficult to distinguish texturally from overbank sediment (Nanson, 1980). There are now sufficient detailed studies of meandering-river floodplains to recognise considerable diversity within the basic model of Wolman and Leopold (1957). 
On the bases of morphology and process, lateral migration floodplains can be subdivided into four sub-orders characterised by: (a) a featureless surface; (b) a scroll-patterned surface; (c) extensive areas of overbank back-swamp deposition along the valley margins; and (d) counterpoint deposition.

\section{Suborder B3a. Lateral migration, non-scrolled floodplains}

These floodplains appear to be characteristic of small streams or rapidly migrating rivers where pronounced levee banks do not form (Wolman and Leopold, 1957). They are not presented here diagramatically because of their similarity to scrolled floodplains described below (Fig. 2ii) and because they are commonly illustrated in a series of readily available texts. Convex-bank deposition builds a point bar which grades imperceptibly into thin, horizontallybedded overbank deposits with no scroll bars. Along some streams with relatively high suspended load to bedload ratios, the authors have observed non-scrolled laterally migrating floodplains formed by oblique accretion of fine grained sediments on to the relatively steep convex bank of a meander bend. Just why floodplain scrolls form along some rivers, but not others, is only partially understood and is considered below.

\section{Suborder B3b. Lateral migration, scrolled floodplains}

These display the characteristic ridge and swale or scroll pattern commonly seen on aerial photographs of meanderingriver floodplains (Fig. 2ii). However, the origin of these ridges is not the same for all rivers. Floodplain scrolls can result from at least three processes in different environments. Sundborg (1956), Nilsson and Martvall (1972) and Jackson (1976) concluded that they result from the landward migration of transverse sand bars on to a point bar, subsequently toped with overbank sediment. The latter process is enhanced by floodplain vegetation preferentially established along the ridge crests. In contrast, Nanson (1980) demonstrated that scrolls can also be initiated by suspended sediment, possibly deposited within a flow-separation envelope over the point bar or concentrated around debris stranded on the point bar near the bend apex (Nanson, 1981); following their inception, scroll bars grow both upstream and downstream. During formation, they appear to generate a convergent flow pattern of secondary currents that moves sediment from the swales towards the ridge crests, thereby maintaining the scroll pattern even in the presence of abundant overbank deposition (Nanson, 1980). Hickin and Nanson (1975) have shown that scroll bars form relatively infrequently (about once every 30 years on the river they studied) but that they develop a wider spacing and form more frequently as the rate of channel migration increases. 
A third mechanism that can lead to a scoll-pattern floodplain on rivers with coarse-grained point bars is the formation of a chute channel between the convex bank and adjacent point bar (McGowan and Gardner, 1970). As the meander bends migrate, the sequential formation of chute channels results in an undulating floodplain surface of ridges and swales.

\section{Suborder B3c. Lateral migration/backswamp floodplains}

Despite considerable emphasis in the early literature on floodplains formed by lateral migration, it has long been recognised that large rivers, such as the Mississippi and some rivers in Papua New Guinea, only form lateral accretion deposits proximal to the channel while laying down extensive deposits of fine-grained overbank sediment along the valley margins (Fisk, 1947, 1952; Speight, 1965; Blake and Ollier, 1971; Kesel et al., 1974; Farrell, 1987) (Fig. 2iii). Certain large estuarine rivers in northern Australia are also of this type (Woodroffe et al., 1989). Apparently these large rivers have only sufficient power to rework part of their massive valley fills, the remainder gradually accumulating as overbank deposition within adjacent backswamps (Fig. 2iii). The result is a composite floodplain formed by two very different processes. Rivers in environments with less stream power than that available here, as for example in deltas, fall into Class C.

\section{Suborder B3d. Lateral migration, counterpoint floodplains}

In confined sections of meandering rivers, where meander bends are forced to reduce their normal curvature due to obstruction, fine-grained and organic sedimentation occurs at high flows in a separation zone against the upstream limb of the convex bank (Fig. 2iv). Termed "counterpoint sedimentation" by Lewin (1983), Nanson and Page (1983) refer to this process as "concave-bench deposition" and demonstrate that up to $30 \%$ of the total floodplain area can be formed as tightly curving meander bends migrating along a valley side. Of all the floodplains in Class B, these are the product of a particularly low-energy localised environment. The surface expression of counterpoint deposits on the floodplain is as a set of scrolls concave to the channel, in contrast to point bars which in plan form are convex to the channel (Fig. 2iv).

\section{Class C. Low-energy cohesive floodplains}


These floodplains are illustrated in Fig. 3.

\section{i) Anastomosing River, Organic-Rich Floodplain $\omega=<10 W^{-2}$}
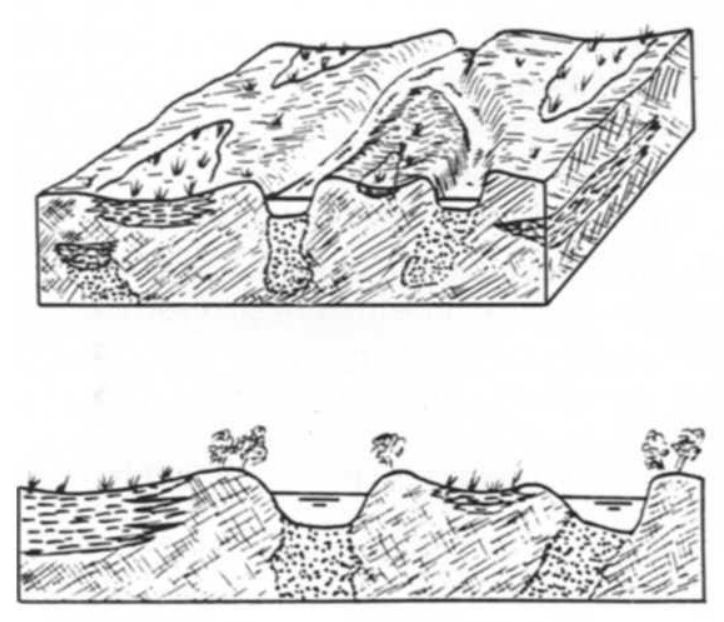

ii) Anastomosing River, Inorganic Floodplain $\omega=<10 \mathrm{Wm}^{-2}$
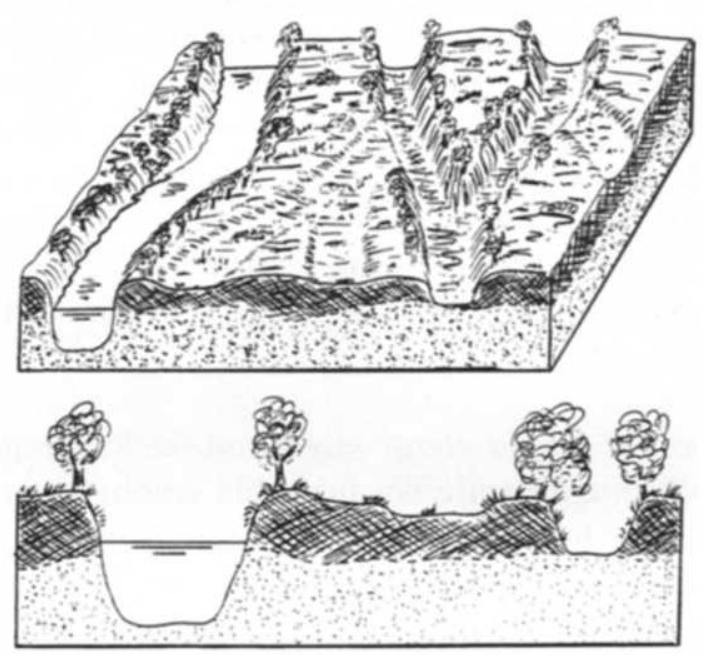

Fig. 3. Low-energy, cohesive floodplains. (i) Anastomosing river, organic-rich floodplains (after Smith and Smith, 1980). Vertical accretion is laying down overbank muds and lacustrine deposits around near-vertical stringers of sand or gravel beneath each channel. Swamps and lakes can result in widespread paludization. (ii) Anastomosing river, inorganic floodplains (after Nanson et al., 1986, 1988 and Rust and Nanson, 1986). To the right of the diagram, anastomosing channels are incised into cohesive floodplain mud with coexistent shallow braid-channels over the floodplain surface. To the left of the diagram, a waterhole has scoured beneath the mud into a sand sheet deposited during an earlier flow regime (Nanson et al., 1988).

\section{Order CI. Laterally stable single-channel floodplains}

Floodplains formed predominantly of overbank deposition along single-thread channels are often characteristic of low energy environments where there is a high proportion of suspended-load material. Beckinsale and Richardson (1964), Rose et al., (1980), Brown (1983), and Macklin (1985) describe thick accumulations of fine grained silty clays and peats within the floodplain sediments of some low-land rivers in England. Brakenridge $(1981,1984,1985)$ describes the dominance of overbank deposits in river systems in the United States which are characterised by very slow rates of lateral migration. Nanson and Young (1981) describe floodplains along coastal valleys in N.S.W., Australia, which exhibit fine-grained vertical accretion sedimentary sequences which they explain in terms of a decrease in channel slope and channel capacity causing a reduction in available stream power. This low power results in fine-grained 
cohesive bank sediments which further inhibit lateral migration of the channel. Croke (1991) also related the dominance of overbank vertical accretion deposits within an upland floodplain environment to a local reduction in stream power and sediment calibre. Floodplains in this Order may possess a variety of depositional landforms such as backswamps, sand splays and low levees. They are not represented here diagramatically because of their similarity to anastomosing-river, organic-rich floodplains (C2a) described below (Fig. 3i).

\section{Order C2. Anastomosing-river floodplains}

Due to their low gradients (commonly less than 0.0002), floodplains in this Order form largely by the overbank deposition of fine-grained sediment in the form of extensive islands with levees, floodbasins and occasional crevasse channels and splays. Minimal channel migration results in a general absence of scrolls and oxbows. It was initially believed that key elements causing a river system to anastomose were rapid sediment aggradation and well vegetated, stable banks in wetland complexes as observed by Smith and Smith, (1980) in North America. From work on anastomosing systems in semi-arid areas of Australia (Rust, 1981; Nanson et al., 1986; Rust and Nanson, 1986; Nanson et al., 1988), it is now recognised that anastomosis is characteristic of rivers with cohesive banks and low stream power and is not necessarily related to stabilising bank vegetation or rapid vertical accretion. The occurrence of anastomosing river systems in a range of climatic environments (alpine, subarctic, humid tropical and semi-arid) indicates that climate is not a controlling factor of anastomosis. However, because of significant differences in the hydrology, geomorphology and sedimentology of the anastomosing-channel floodplains of humid areas (Smith, 1983, 1986; Smith and Smith, 1980) compared to semi-arid regions (Nanson et al., 1986; Nanson et al., 1988), they are recognised here as two distinct sub-orders.

\section{Suborder C2a. Anastomosing river, organic-rich floodplains}

These have been described for humid mountainous and humid plains environments in both alpine/subarctic and tropical regions of the Americas (Smith and Smith, 1980; Smith, 1983, 1986). Channels of normally low sinuosity are flanked by prominent levees that rim islands and enclose interior swamps and lakes and produce well vegetated floodplains of fine sands, silts, clays and organics (Fig. 3i). Bed material varies from gravel (in selected alpine 
locations) to mostly sand; cohesive banks of silt and clay are reinforced with extensive vegetation root-mats (Smith, 1976). Six sediment facies have been recognised: channel, levee, crevasse splay, peat bog, backswamp, and lacustrine. In contrast to those described below, organic and lacustrine deposits are a significant characteristic of these floodplains which show high rates of vertical accretion. Rates determined thus far vary from 4 to $60 \mathrm{~mm} \mathrm{yr}^{-1}$ and are related to reduced local gradients where alluvial fans have partially blocked rivers, rapidly subsiding basins and prograding deltas.

\section{Suborder C2b. Anastomosing river, inorganic floodplains}

These have been described from semi-arid low-gradient depositional basins in central Australia where anastomosing ephemeral channels operating at both low and high flows coexist with a system of braided floodplain channels that transport mud as sand-sized pedogenic aggregates during overbank flows (Nanson et al., 1986; Rust and Nanson, 1986). Vegetation is relatively sparse although the anastomosing channels are often tree-lined, have low width/depth ratios, transport little sand and are incised into very cohesive mud (Fig. 3ii). Floodplain sediment facies are dominated by channel, levee, crevasse splay and "arid" backswamp deposits with little or no organics. The floodplain braidchannels are free of trees, very broad and shallow and may initiate at, terminate at or cross over the anastomosing channels, suggesting that the two systems are interactive in their transport of floodwater and sediment. The presence of a network of mud-load braid channels over floodplains of such low gradient is related to the transport of the mud as abundant, sand-sized and water-stable mud aggregates of relatively low density derived from vertisols that form on these alluvial deposits (Nanson et al., 1986, 1988). In places where localised gradients and flow depths permit, the anastomosing channels enlarge into permanent waterholes, 8-16 m deep (at bankfull) and several kilometers in length (Fig. 3ii). Despite frequent overbank flooding, thermoluminescence dating has shown these floodplains to be vertically accreting at about 0.02 to $0.05 \mathrm{~mm} \mathrm{yr}^{-1}$ (Nanson et al., 1988), two or three orders of magnitude less than those in Order $\mathrm{C} 2 \mathrm{a}$ above. These low rates are due to extremely low suspended-sediment concentrations with the mud being aggregated and transported as bedload.

\section{Floodplain transformations}

River channels change in response to environmental variations that alter flow or sediment regime (e.g. Schumm, 1977; Ferguson, 1987; and reviews by Hickin 1983 and Gregory and Lewin, 1987). Fundamental to the genetic classification 
proposed here is the recognition that a floodplain will also change in response to environmental variations that affect the channel, although usually more slowly. The floodplain may be resistant to change or, because of distance from the active channel, it may not be reworked by channel migration for some hundreds or thousands of years. Inevitably, however, there will be a shift from one floodplain type to another. The proposed floodplain transformations are summarised in Table 2 where it is recognised that floodplain changes are reversible under the opposite sets of conditions. Such transformations can be spatial, as along a single valley, or temporal, as a result of changing flow or sediment conditions.

Table 2. Floodplain transformations

\section{Floodplain transformations}

\begin{tabular}{ll}
\hline Floodplain orders and suborders & Variables \\
\hline Class A transformations & \\
$\mathrm{A}_{\mathrm{i}} \rightarrow \mathrm{B} 1_{\mathrm{G}}$ & $\left(V_{w}^{+}, \Omega^{+}, W^{+}, \omega^{-}\right)$ \\
$\mathrm{A} 2 \rightarrow \mathrm{A} 3$ & $\left(V_{w}^{+}, W^{+}, \omega^{-}\right)$ \\
$\mathrm{A} 2 \rightarrow \mathrm{B} 1_{\mathrm{s}}$ & $\left(V_{\mathrm{w}}^{+}, \Omega^{+}, \mathrm{Q}_{\mathrm{s}}^{+}, \mathrm{W}^{+}, \omega^{-}\right)$ \\
$\mathrm{A} 3 \rightarrow \mathrm{B} 1_{\mathrm{s}}$ & $\left(\Omega^{+}, \mathrm{Q}_{\mathrm{s}}^{+}, \mathrm{W}^{+}, \omega^{-}\right)$ \\
$\mathrm{A} 3 \rightarrow \mathrm{A} 4, \mathrm{C} 1$ & $\left(\Omega^{-}, \mathrm{Q}_{\mathrm{s}}^{-}, \mathrm{D}_{\mathrm{s}}^{-}\right)$ \\
Ciass B transformations & \\
$\mathrm{B} 1 \rightarrow \mathrm{B} 2 \rightarrow \mathrm{B} 3 \mathrm{a}$ or $\mathrm{b} \rightarrow \mathrm{B} 3 \mathrm{c} \rightarrow \mathrm{C} 1$ or & $\left(\Omega^{-}, \mathrm{Q}_{\mathrm{s}}^{-}, \mathrm{D}_{\mathrm{s}}^{-}, \mathrm{W}^{-}\right.$, \\
$\mathrm{C} 2$ & $\left.\omega^{-}\right)$ \\
Ciass C transformations & \\
$\mathrm{C} 1 \rightarrow \mathrm{C} 2$ & $\left(\mathrm{Q}^{+}, \omega^{0}\right)$
\end{tabular}

$V_{w}=$ Valley width; I= Gross stream power; I= Individual channel width; $\omega=$ Specific stream power; $Q_{\mathrm{S}}=$ Quantity of sediment load; $D_{\mathrm{S}}=$ Calibre of sediment load; $Q=$ Discharge; $B 1_{\mathrm{G}}=$ Braided gravel river; $B 1_{\mathrm{S}}=$ Braided sandy river; $+=$ increase $;-=$ decrease ${ }^{0}=$ no change.

NB: These floodplain transformations are reversible.

In Class A (High-Energy, Non-Cohesive Floodplains) floodplains can change both within and between classes. For example, with an increase in valley width, a Confined Coarse-Textured Floodplain (A1) could become a gravelly Braided River Floodplain (Bl), although this might also require an increase in gross stream-power but spread across a wider channel and valley cross-section (hence a lower specific stream-power; Table 2). Braiding in headwater valleys is not uncommon along wide reaches (e.g. Stewart and Lamarche, 1967). Under similar conditions, Confined VerticalAccretion Sandy Floodplains (A2) could convert to the unconfined equivalent (A3) or to a sandy Braided River Floodplain (Bl). With a decline in the total power available, a decrease in the quantity of the sediment load, a slight increase in alluvial cohesion (the proportion of silt and clay) and a more episodic (catastrophic) flow regime, an Unconfined Vertical-Accretion Sandy Floodplain (A3) could convert to a Cut and Fill Floodplain (A4). A2 
floodplains in high-energy sandy alluvial valleys of coastal New South Wales (Nanson, 1986) appear to be substituted with A4 floodplains (Erskine, 1986b) in smaller, lower-energy sandy environments in the same region. In upland dells, the binding effect of vegetation may also be important for this transition (Young, 1986; Prosser, 1988). A further substantial reduction in stream power and a concomitant increase in sediment cohesion could result in a jump from Class A to Class C to form of a Laterally Stable Single-Channel Floodplain (C1); this transition has been observed at the lower end of Wollombi Brook in eastern Australia (Erskine, 1986b).

In Class B, with a decline in stream power and associated sediment calibre and load, transformation from one floodplain type to another follows a predictable sequence from B1 to B3c (Table 2). Excluded from this progression are Lateral Migration Counterpoint Floodplains (B3d); these are not usually related to an overall very-low specific stream-power but rather to the localised low-energy conditions of a separation zone against the concave bank of a bend. With a further reduction in energy in the sequence, the channel associated with a Laterally Migrating/Backswamp Floodplain (B3c) will lose almost all its ability to migrate and will then form a Laterally Stable Single-Channel Floodplain (C1) or an Anastomosing River Floodplain (C2); this can occur at the transition of a river floodplain and its low-energy delta.

While river braiding is believed to be, in part, due to an abundant supply of non-cohesive sediment that is stored in the channel as bars (e.g. Knighton, 1984; Ashmore, 1991), the cause of the other multi channelled river state, anastomosis, has never been adequately explained. It is proposed here that anastomosis may be the product of an abundant supply of water over low-gradient unconfined and relatively cohesive (or well-vegetated) floodplains. This appears to be true even for the arid environments of central Australia were anastomosing channels result from a seasonally abundant water supply provided by the northern monsoon. It is proposed in Table 2 that Laterally Stable Single-Channel Floodplains (C1) will develop anastomosing channels (and hence become C2 floodplains) under conditions of increased flow over cohesive or well vegetated floodplains; much of this increased discharge will travel overbank or in multiple channels, affecting little change in specific stream-power.

While the floodplain transformations proposed in Table 2 require further substantiation, the sequence provides testable hypotheses for examining energy or sediment based changes in river floodplains, either spatial or temporal.

\section{Conclusion}


Although floodplains are complex multivariate landforms it is possible to classify them on the basis of reasonably objective criteria. A useful delineation of floodplain types is made here initially on the basis of stream power and sediment texture and with further subdivision on the basis of geomorphic characteristics. Because rivers and their floodplains change in a systematic fashion with declining stream power and sediment texture, it is possible to develop a ranking of floodplains into three distinct classes. Thirteen floodplain orders and suborders are differentiated on the basis of nine factors that are mostly floodplain geomorphic processes. However, these processes and resulting landforms are not necessarily exclusive to a particular floodplain category and, therefore, floodplain orders and suborders have been determined on the dominance of a set of landforms and processes. The resulting floodplain categories are distinctive in terms of their genesis and morphology.

Like all classifications, this one involves simplification and a resultant loss of information. However, the hierarchy of floodplain types forms a logical pattern that may help to focus research by drawing attention to poorly understood aspects, such as the formation of braided river floodplains and the variety of types of anastomosing floodplains and their causes. Research in this area is incomplete and further work will contribute to modification of this scheme. Particular attention should be paid to discriminating floodplains on the basis of stream power; the existing literature contains little data suitable for accurate estimations and, consequently, the categories given here require refinement. While recognising that in some environments there is not a simple association between sedimentation patterns and channel-floodplain styles (e.g. Brierley and Hickin, 1991 ), this scheme could be expanded to permit the inclusion of more detailed sedimentological data that would allow its use in identifying floodplain environments from the stratigraphic record. The result would build upon the sedimentary architecture models proposed by Miall (1985).

\section{Acknowledgements}

This paper owes its existence to a suggestion made nearly two decades ago by Ted Hickin of Simon Fraser University; we believe the delay between suggestion and implementation has improved its content. The manuscript has benefited greatly from discussion and input willingly provided by Gary Brierley, Ted Bryant, Ivars Reinfields, Mike Church and John Lewin although we accept readily that its various shortcomings remain our responsibility.

\section{References}


Allen, J.R.L., 1965. A Review of the origin and character of recent alluvial sediments. Sedimentology, 5: 89-191.

Allen, J.R.L., 1970. A quantitative model of grain size and sedimentary structure in lateral deposits. Geol. J., 7: 129146.

Anderson, M.G. and Calver, A., 1977. On the persistence of landscape features formed by a large flood; Trans. Inst. Br. Geogr. New Ser., 2: 243-254.

Anderson, M.G. and Calver, A., 1980. Channel plan changes following large floods. In: R.A. Cullingford, D.A. Davidson and J. Lewin (Editors), Timescales in Geomorphology. Wiley, Chichester, pp. 43-52.

Ashmore, P.E., 1991. How do gravel rivers braid?, Can. J. Earth Sci., 28: 326-341.

Bagnold, R.A., 1966. An approach to the sediment transport problem from general physics. U.S. Geol. Surv. Prof. Pap., 4221.

Bagnold, RA., 1977. Bed load transport by natural rivers. Water Resour. Res., 13: 303-312.

Baker, V.R., 1977. Stream channel response to floods with examples from central Texas. Bull. Geol. Soc. Am., 88: 1057-1071.

Beckinsale, R.P. and Richardson, L., 1964. Recent findings on the physical development of the lower Severn valley. Geogr. J., 130: 87-105.

Blake, D.H. and OIlier, C.D., 1971. Alluvial plains of the Fly River, Papua. Z. Geomorph. Suppl., 12: 1-17.

Bluck, B.J., 1971. Sedimentation in the meandering River Endrick. Scott. J. Geol., 7: 93-138.

Bluck, B.J., 1974. Structure and depositional properties of some valley sandur deposits in southern Iceland. Sedimentology, 21: 533-554.

Boothroyd, J.C. and Nummedal, D., 1978. Proglacial braided outwash: a model for humid alluvial fan deposits. In: A.D. Miall (Editor), Fluvial Sedimentology. Can. Soc. Petrol. Geol. Calgary, Mem., 5: 641-668.

Brakenridge, G.R., 1981. Late Quaternary floodplain sedimentation along the Pomme de Terre, southern Missouri. Quat. Res., 15: 62-76.

Brakenridge, G.R., 1984. Alluvial stratigraphy and radiocarbon dating along the Duck River, Tennessee: Implications regarding floodplain origin. Bull. Geol. Soc. Am., 95: 9-25.

Brakenridge, G.R., 1985. Rate estimates to lateral bedrock erosion based on radiocarbon ages, Duck River, Tennessee. Geology, 13: 111-114.

Brakenridge, G.R., 1987. River flood regime and floodplain stratigraphy. In: V.R Baker, Re. Kochel and P.C. Platton (Editors), Flood Geomorphology, Wiley, Chichester, pp. 139-157. 
Bridge, J.S., 1985. Palaeochannel patterns inferred from alluvial deposits: a critical evaluation. J. Sed. Petrol., 55: 579589.

Bridge, J.S. and Leeder, M.R., 1979. A simulation model of alluvial stratigraphy. Sedimentology, 26: 617-644.

Brierley, G.J., 1991. Three-dimensional elemental floodplain sedimentology of the Squamish River, British

Columbia. Sedimentology, 38: 735-750.

Brierley, G.J. and Hickin, E.J., 1991. Channel planform as a non-controlling factor in fluvial sedimentology; the case of the Squamish River floodplain, British Columbia. Sed. Geol., 75(1/2): 67-83.

Bristow, C.S., 1987. Brahmaputra River: Channel migration and deposition. In: F.G. Ethridge, RM. Flores and M.D. Harvey (Editors), Recent Developments in Fluvial Sedimentology. Soc. Econ. Palaeontol. Mineral. Spec. Publ., 39: 63-74.

Brotherton, D.I., 1979. On the origin and characteristics of river form. J. Hydraul. Eng., 44: 230. Brown, A.G., 1983. Floodplain deposits and accelerated sedimentation in the lower Severn Basin. In: K.J. Gregory (Editor), Background to Palaeohydrology: A Perspective. Wiley, Chichester, pp. 375-390.

Brown, A.G., 1990. Holocene floodplain diachronism and inherited downstream variations in fluvial processes; a study of the River Perry, Shropshire, England. J. Quat. Sci., 5, 39-51.

Bryan, K., 1922. Erosion and sedimentation in the Papago country, Arizona. Bull. U.S. Geol. Surv., 730-B: 19-90.

Bull, W.B., 1979. Threshold of critical power in streams. Bull. Geol. Soc. Am., 90: 453-464.

Burrin, P.J., 1985. Holocene alluviation in southeast England and some implications for palaeohydrological studies. Earth Surf. Proc. Landforms, 10: 257-271.

Burrin, P.J. and Scaife, R.G., 1984. Aspects of Holocene valley sedimentation in Southern England. Proc. Geol. Assoc., 95: 81-96.

Burkham, D.E., 1972. Channel changes of the Gila river in Safford valley, Arizona, 1864-1970. U.S. Geol. Surv. Prof. Pap., 655G.

Butzer, K.W., 1976. Geomorphology from the Earth. Harper and Row, New York, 463 pp.

Carling, P., 1986. The Noon Hill flash floods, July $17^{\text {th }}$ 1983: hydrological and geomorphological aspects of a major formative event in an upland landscape. Trans. Inst. Br. Geogr., II: 105-118.

Carey, W.C., 1969. Formation of floodplain lands. J. Hydraul. Div., Am. Assoc. Civil Eng., 95 (HY3): 981-994.

Carson, M.A., 1984. Observations on the meandering braided river transition, Canterbury Plains, New Zealand. N.Z. Geogr., 40: 12-17, 89-99.

Carson, M.A. and Griffiths, G.A., 1987. Bedload transport in gravel channels. J. Hydrol., 26: 1-151. 
Carson, M.A. and Griffiths, G.A., 1989. Gravel transport in the braided Walmakariri River: mechanisms, measurements and predictions. J. Hydrol., 109: 201-220.

Church, M., 1983. Patterns of instability in a wandering gravel bed channel. In: J.D. Collinson and J. Lewin (Editors), Modern and Ancient Fluvial systems. Inst. Assoc. Sedimentol. Spec. Publ., 6: 169-180.

Coleman, J.M., 1969. Brahmaputra River: Channel processes and sedimentation. Sed. Geol., 3: 129-239.

Croke, J.C., 1991. Floodplain variability in the Glenmalure Valley, southeast Leinster, Ireland. PhD Thesis, National University of Ireland, unpubl.

Dana, J.D., 1863. Manual of Geology. Philadelphia, 796 pp.

Davis, W.M., 1898. Physical Geography. Ginn and Co., Boston, 432 pp.

Desloges, J.R. and Church, M., 1987. Channel and floodplain facies in a wandering gravel-bed river. In: F.G. Ethridge, R.M. FLores and M.D. Harvey (Editors), Recent Developments in FLuvial Sedimentology. Soc. Economic Palaeontol. Mineral. Spec. Publ., 39: 99-109.

Dietrich, W.E., 1987. Mechanics of flow and sediment transport in river bends. In: K. Richards (Editor), River Channels: Environment and Process. Blackwells, Oxford, pp. 179-227.

Doeglas, D.J., 1962. Structure of sedimentary deposits of braided rivers. Sedimentology, 1: 167-190.

Dott, R.H., Jr. and Bourgeois, J., 1983. Hummocky stratification: significance of its variable bedding sequences: reply to discussion by R.G. Walker et al., Bull. Geol. Soc. Am., 94: 1245-1251.

Douglas, I., 1977. Humid Landforms. Australian National University Press, Canberra, 288 pp.

Dury, G.H., 1982. Step-functional analysis of long records of streamflow. Catena, 9: 379-396.

Erskine, W.D., 1986a. River metamorphosis and environmental change in the Macdonald valley N.S.W. since 1949. Aust. Geogr. Stud., 241: 88-107.

Erskine, W.D., 1986b. River metamorphosis and environmental change in the Hunter valley, New South Wales. PhD thesis, University of New South Wales, unpubl.

Erskine, W.D. and Bell, F.C., 1982. Rainfall, floods and river channel changes in the upper Hunter. Aust. Geogr. Stud., 20: 183-196.

Erskine, W.D. and Warner, R.F., 1988. Geomorphic effects of alternating flood- and drought-dominated regimes on N.S.W. coastal rivers. In: R.F. Warner (Editor), Fluvial Geomorphology of Australia. Academic Press, Sydney, pp. 223-242.

Eyles, R.J., 1977. Changes in drainage networks since 1820, southern Tablelands, N.S.W. Aust. Geogr., 13: 377-386. 
Fahnstock, R.K, 1963. Morphology and hydrology of a glacial stream - White River, Mount Ranier, Washington. U.S. Geol. Surv. Prof. Pap., 422A.

Farrell, K.J., 1987. Sedimentology and facies architecture of overbank deposits of the Mississippi River, False River region, Louisiana. In: F.G Ethridge, R.M. Flores and M.D. Harvey (Editors), Recent Developments in Fluvial Sedimentology. Soc. Econ. Palaeontol. Mineral. Spec. Publ., 39: 111-121.

Fenneman, N.M., 1906. Floodplains produced without floods. Bull. Geol. Soc. Am., 38: 89-91.

Ferguson, R.I., 1981. Channel form and channel changes. In: J. Lewin (Editor), British Rivers. Allen \& Unwin, London, pp. 90-125.

Ferguson, R.I., 1987. Hydraulic and sedimentary controls of channel pattern. In: K. Richards (Editor), Rivers Environment and Process. Blackwell, Oxford, pp. 129-158.

Ferguson, R.I. and Ashworth, P., 1991. Slope induced changes in channel character along a gravel-bed stream: the Allt Dubhaig, Scotland. Earth Surf. Proc. Landforms, 16: 65-82.

Fisk, H.N., 1944. Geological investigation of the alluvial valley of the lower Mississippi River, U.S. Army Corps Eng., Mississippi River Commission, Vicksburg, Miss.

Fisk, H.N., 1947. Fine grained alluvial deposits and their effects on the Mississippi River activity. U.S. Waterways Experimental Station.

Fisk, H.N., 1952. Mississippi River valley geology in relation to river regime. Trans. Am. Soc. Civil Eng., 117: 667689.

Froelich, W., Kaszowski, L. and Starkel, L., 1977. Studies of present day and past river activity in the Polish Carpathians. In: K.I. Gregory (Editor), River Channel Changes. Wiley, Chichester: pp. 411-422.

Galay, V.I., Kellerhals, R. and Bray, D.L, 1973. Diversity of river types in Canada. In: Fluvial Processes and Sedimentation. Proc. Hydrologists Symp. Edmonton, National Research Council, pp. 217-250.

Galloway, W.E., 1981. Depositional architecture of Cenozoic Gulf Coastal Plain fluvial systems. In: F.G. Ethridge and R.M. Flores (Editors), Recent and Ancient Nonmarine Depositional Environments. Soc. Econ. Palaeontol. Mineral. Spec. Publ., 31: 127-156.

Gilbert, G.K, 1877. Report on the Geology of the Henry Mountains. United States Geological and Geographical Survey, Rocky Mountain Region, General Printing Office, Washington, DC.

Graf, W.L., 1983a. Flood-related change in an arid region river. Earth Surf. Proc. Landforms, 8: 125-139.

Graf, W.L., 1983b. The arroyo problem - palaeohydrology and palaeohydraulics in the short term. In: KJ. Gregory (Editor), Background to Palaeohydrology - A Perspective, Wiley, New York, pp. 279-302. 
Graf, W.L., 1984. A probabilistic approach to the spatial assessment of river channel instability. Water Resour. Res., 20: $953-962$.

Graf, W.L., 1988. Fluvial Processes in Dryland Rivers. Springer, Berlin.

Gregory, KJ. and Lewin, J., 1987. Conclusions; Palaeohydrological synthesis and application. In: K.J. Gregory, J. Lewin and J.B. Thornes (Editors), Palaeohydrology in Practice; A River Basin Analysis. Wiley, Chichester, pp. 341-360.

Griffiths, G.A., 1979. Recent sedimentation history of the Walmakariri River, New Zealand. J. Hydrol. (New Zealand), 18: 6-28.

Happ, S.C., Rittenhouse, G. and Dobson, G.C., 1940. Some principles of accelerated stream and valley sedimentation. U.S. Dep. Agric. Tech. Bull., 695: 121 pp.

Hickin, E.J., 1979. Concave-bank benches on the Squamish River, British Columbia, Canada. Can. J. Earth Sci., 16: 200-203.

Hickin, E.J., 1983. River channel changes: retrospect and prospect. In: J.D. Collinson and J. Lewin (Editors), Modern and Ancient Fluvial Systems. Spec. Publ. Int. Assoc. Sedimentol., 6: 61-83.

Hickin, EJ., 1983. Vegetation and river channel dynamics. Can. Geogr., 18: 111-126.

Hickin, EJ. and Nanson, G.C., 1975. The character of channel migration on the Beatton River, north-east British Columbia, Canada. Bull. Geol. Soc. Am., 86: 487-494.

Hickin, EJ. and Nanson, G.C., 1984. Lateral migration rates of river bends. J. Hydraul. Eng., 110/111: 1557-1567.

Hjulstrum, F., 1935. Studies of the morphological activities of rivers as illustrated by the River Fyris. Bull. Geol. Inst., Univ. Uppsala, 25: 221-527.

Hydraulic Engineering Centre, 1976. Scour and deposition in rivers and reservoirs. User's Manual 723-G2-L2470, U.S. Army Corps Engineering.

Jackson, R.G., 1976. Depositional model of point bars in the Lower Wabash River. J. Sed. Petrol., 46: 579-594.

Jackson, R.G., 1978. Preliminary evaluation of lithofacies models for meandering alluvial streams. In: A.D. Miall (Editor), Fluvial Sedimentology. Can. Soc. Petrol. Geol. Calgary, Mem., 5: 543-576.

Kellerhals, R., Neill, C.R. and Bray, D.I., 1972. Hydraulic and geomorphic characteristics of rivers in Alberta. Res. Council of Alberta, River Engineering and Surface Hydrology, Rep. 72-1. Edmonton, Alta, 52 pp.

Kellerhals, R., Church, M. and Bray, D.I., 1976. Classification and analysis of river processes. J. Hydraul. Div. Proc. Am. Soc. Civil Eng., 102: HY7.

Kesel, R.H., Dunn, R., McDonald, C. and Allison, K.R., 1974. Lateral erosion and overbank deposition in the 
Mississippi River in Louisiana caused by 1973 flooding. Geol., 2: 461-464.

Knighton, A.D., 1984. Fluvial Forms and Processes. Edward Arnold, London.

Knighton, A.D., 1987. River Channel Adjustment - the Downstream Dimension. In: K.J. Richards (Editor), River Channels: Environment and Process. Blackwell, Oxford, pp. 95-127.

Kngstrom, A., 1962. Geomorphic studies of sandur plains and their braided rivers in Iceland. Geogr. Annala, 44: 328346.

Lattman, L.H., 1960. Cross section of a floodplain in a moist region of moderate relief. J. Sed. Petrol., 30: 275-282.

Leeder, M., 1978. A quantitative stratigraphic model for alluvium with specific reference to channel deposit density and interconnectedness. In: A.D. Miall (Editor), Fluvial Sedimentology. Can. Soc. Petrol. Geol. Calgary, Mem., 5: 587-597.

Leopold, L.B. and Wolman, M.G., 1957. River channel patterns - braiding, meandering and straight. U.S. Geol. Surv. Prof. Pap., 282B.

Leopold, L.B., Wolman, M.G. and Miller, J.P., 1963. Fluvial Processes in Geomorphology. Freeman, San Francisco, $522 \mathrm{pp}$.

Lewin, J., 1978. Floodplain geomorphology. Prog. Phys. Geogr., 2: 408-437.

Lewin, J., 1983. Changes of channel patterns and floodplains. In: KJ. Gregory (Editor), Background to Palaeohydrology: A Perspective. Wiley, Chichester, pp. 161-175.

Lewin, J. and Weir, M.J.C., 1977. Morphology and recent history of the Lower Spey. Scott. Geogr. Mag., 93: 45-51.

Lewis, G.W. and Lewin, J., 1983. Alluvial cuttoffs in Wales and the Borderlands. In: J. Collinson and J. Lewin

(Editors), Modern and Ancient Fluvial Systems. Int. Assoc. Sedimentol. Spec. Publ., 6: 145-154.

Lyall, C., 1867. Principles of Geology, 1, 10th ed. Murray, London, 671 pp.

Mackel, R., 1974. Dambos: A study of morphodynamic activity on the plateau regions of Zambia. Catena, 1: 327-365.

Mackin, J.H., 1936. Erosional history of the Big Horn Basin, Wyoming. Bull. Geol. Soc. Am., 48: 813-894.

Macklin, M.G., 1985. Floodplain sedimentation in the Upper Axe Valley, Mendip, England. Trans. Inst. Br. Geogr. New Ser., 10: 235-244.

McGowan, J.H. and Garder, L.E., 1970. Physiographic features and stratification types of coarse-grained point bars: Modern and ancient examples. Sedimentology, 14: 77-111.

Melton, F.A., 1936. An empirical classification of floodplain streams. Geogr. Rev., 26: 593-609.

Miall, A.D., 1977. A review of the braided river depositional environment. Earth Sci. Rev., 13: 1-62. 
Miall, A.D., 1985. Architectural element analysis: A new method of facies analysis applied to fluvial deposits. Earth Sci. Rev., 22: 261-308.

Miall, A.D., 1987. Recent developments in the study of facies models. In: F.G. Ethridge, R.M. Flores and M.D. Harvey (Editors), Recent Developments in Fluvial Sedimentology. Soc. Econ. Palaeontol. Mineral. Spec. Publ., 39: 1-9.

Mollard, J.D., 1973. Alrphoto interpretation of fluvial features. In: Fluvial Processes and Sedimentation. Proc. 9th Can. Hydrologist's Symp., Edmonton, pp. 341-380.

Moseley, M.P., 1987. The classification and characterization of rivers. In: K. Richards (Editor), Rivers - Environment and Process. Blackwell, Oxford, pp. 295-320.

Mycielska-Dowgiallo, E., 1977. Channel pattern changes during the last Glaciation and Holocene in the northern part of the Sandormievz Basin and the middle part of the Vistula valley, Poland. In: K.J. Gregory (Editor), River Channel Changes, Wiley, Chichester, pp. 75-91.

Nanson, G.C., 1980. Point bar and floodplain development of the meandering Beatton River, northeastern British Columbia, Canada. Sedimentology, 27: 3-29.

Nanson, G.C., 1981. New evidence of scroll bar formation on the Beatton River. Sedimentology, 28: 889-891.

Nanson, G.C., 1986. Episodes of vertical accretion and catastrophic stripping: a mode of disequilibrium floodplain development. Bull. Geol. Soc. Am., 97: 1467-1475.

Nanson, G.C. and Erskine, W.D., 1988. Episodic changes of channels and floodplains on coastal rivers in N.S.W. In: R.F. Warner (Editor), Fluvial Geomorphology of Australia. Academic Press, Sydney, pp. 201-221.

Nanson, G.C. and Hickin, E.J., 1986. A statistical analysis of bank erosion and channel migration in Western Canada. Bull. Geol. Soc. Am., 97: 497-504.

Nanson, G.C. and Page, K.J., 1983. Lateral accretion of fine grained concave benches on meandering rivers. In: J. Collinson and J. Lewin (Editors), Modern and Ancient Fluvial Systems. Int. Assoc. Sedimentol. Spec. Publ., 6: $133-145$.

Nanson, G.C. and Young, R.W., 1981. Overbank deposition and floodplain formation on small coastal streams of New South Wales. Z. Geomorph., 25: 332-347.

Nanson, G.C., Rust, B.R. and Taylor, G., 1986. Coexistent mud braids and anastomosing channels in an aridzone river: Cooper creek, central Australia. Geology, 14: 175-178.

Nanson, G.C., Young, R.W., Price, D.M. and Rust, B.R., 1988. Stratigraphy, sedimentology and Late Quaternary 
chronology of the Channel Country of Western Queensland. In: R.F. Warner (Editor), Fluvial Geomorphology of Australia. Academic Press, Sydney, pp. 151-175.

Nilsson, G. and Martvall, S., 1972. The Ore River and its meanders. Uppsala University, Dept., Phys., Geography, Urgi Rep., 19: 154 pp.

Nordseth, N., 1973. Floodplain construction on a braided river: The islands of Koppangoyene on the River Glomma. Norsk Geogr. Tidsskrift, 27: 109-126.

Page, K.J. and Nanson, G.C., 1982. Concave bank benches and associated floodplain formation. Earth Surf. Proc. Landforms, 7: 529-543.

Page, K.J. and Mowbray, P.D., 1983. Cutoff and oxbow lake. Aust. Geogr., 15: 177-180.

Petts, G.E. and Foster, I.D.L., 1985. Rivers and Landscape. Edward Arnold, London.

Pickup, G., 1984. Geomorphology of tropical rivers. I. Landforms, hydrology and sedimentation of the Fly and lower Purari, Papua New Guinea. Catena, Suppl., 5: 1-17.

Pickup, G., 1986. Fluvial landforms. In: D.N. Jeans (Editor), Australia - A Geography, 2nd Ed. University Press, Sydney, pp. 148-179.

Popov, I. V., 1964. Hydromorphological principles of the theory of channel processes and their use in hydrotechnical planning. Sov. Hydrol., 3: 188-195.

Prosser, I., 1988. Drainage basin denudation during the Late Quaternary at Wangrah Creek, N.S.W., Australia. PhD thesis, Australian National University, Canberra, unpubl.

Reinfields, LV., 1991. The characteristics and formation of braided-river floodplains, Waimakarirs River, New Zealand, B.Sc. Thesis, University of Wollongong.

Richards, K.S., 1982. Rivers: Form and Process in Alluvial Channels. Methuen, London.

Ritter, D.F., 1975.Stratigraphical implications of coarse grained gravel deposited as overbank sediment, southern Illinois. J. Geol., 83: 1515-1520.

Ritter, D.F., 1978. Process Geomorphology. W.C. Brown, Iowa, 603 pp.

Ritter, D.F., Kinsey, W.F. and Kauffman, M.E., 1973. Overbank sedimentation in the Delaware River valley during the last 6,000 years. Science, 179: 374-375.

Rose, J., Turner, C., Coope, G.R. and Byran, M.D., 1980. Channel Change in a low-land river catchment over the past 13,000 years. In: R.A. Cullingford, D.A. Davidson, and J. Lewin (Editors), Timescales in Geography. Wiley, Chichester. pp. 159-175.

Rust, B.R., 1972. Structure and process in a braided river. Sedimentology, 18: 221-245. 
Rust, B.R., 1978. A classification of alluvial channel systems. In: A.D. Miall (Editor), Fluvial Sedimentology. Can. Soc. Petrol. Geol., Calgary, Mem., 5: 187-198.

Rust, B.R., 1981. Sedimentation in an arid-zone anastomosing fluvial system: Cooper Creek, central Australia. J. Sed. Petrol., 51: 745-755.

Rust, B.G. and Nanson, G.C., 1986. Contemporary and palaeochannel patterns and the Late Quaternary stratigraphy of Cooper Creek, southwest Queensland, Australia. Earth Surf. Proc. landforms, 11: 581-590.

Russell, I.C., 1898. River Development as Illustrated by the Rivers of North America. G.P. Patnams, New York, $327 \mathrm{pp}$.

Schmudde, T.H., 1963. Some aspects of the lower Missouri river floodplain. Ann. Assoc. Am. Geogr., 53: 60-73.

Schumm, S.A., 1968. River adjustment to altered hydrologic regimen - Murrumbidgee River and palaeochannels, Australia. U. S. Geol. Surv. Prof. Pap., 598: 65 pp.

Schumm, S.A., 1973. Geomorphic thresholds and complex response of drainage systems. In: M. Morisawa (Editor), Fluvial Geomorphology. Binghamton, New York, pp. 299-309.

Schumm, S.A., 1977. The Fluvial System. Wiley, New York.

Schumm, S.A., 1979. Geomorphic threshold: the concept and its applications. Trans. Inst. Br. Geogr., New Ser., 4: 485-515.

Schumm, S.A. and Hadley, R.F., 1957. Arroyos and the semi-arid cycle of erosion. Am. J. Sci., 255: 161-174.

Schumm, S.A. and Khan, H.R., 1972. Experimental study of channel patterns. Bull. Geol. Soc. Am., 83: 1755-1770.

Schumm, S.A. and Lichty, R.W., 1963. Channel widening and floodplain construction along Cimarron River in South Western Kansas. U.S. Geol. Surv. Prof. Pap., 352-D; 71-78.

Schields, A., 1936. Anwendung der Aehnlichkeitsmechanik und der turbulenz-forschung auf die geschiebebewegung. Mitteilung der Preussichen versuchsanstalt fuer Wasserbau und Schiflbau, Heft 26, Berlin.

Simons, D.B. and Richardson, E.V. and Nordin, C.F., 1965. Bedload equation for ripples and dunes. U.S. Geol. Surv. Prof. pap., $462 \mathrm{H}$.

Smith ,D.G., 1974. Aggradation of the Alexandra-North Saskatchewan River, Banff Park, Alberta. In: M. Morisawa (Editor), Fluvial Geomorphology. Binghampton, New York, pp. 201-219.

Smith, D.G., 1976. Effect of vegetation on lateral migration of anastomosed channels of a glacial meltwater river. Bull. Geol. Soc. Am., 87: 857-860.

Smith, D.G., 1983. Anastomosed fluvial deposits: modern examples from Western Canada. In: J.D. Collinson and J. Lewin (Editors) ,Modern and Ancient Fluvial Systems. Int. Assoc. Sedimentol. Spec. Publ. 6: 155-168. 
Smith, D.G., 1986. Anastomosing river deposits, sedimentation rates and basin subsidence, Magdalena River, northwestern Colombia, South America. Sed. Geol., 46: 177-196.

Smith, D.G. and Smith, N.D., 1980. Sedimentation in anastomosed river systems: examples from alluvial valleys near Banff, Alberta. J. Sed. Petrol., 50: 157-164.

Smith, N.D., 1971. Transverse bars and braiding in the lower Platte River, Nebraska. Bull. Geol. Soc. Am., 82: 34073420.

Smith, S.A., 1987. Gravel counterpoint bars: examples from the River Tywi, south Wales. In: F.G. Ethridge, R.M. Flores and M.D. Harvey (Editors), Recent Developments in Fluvial Sedimentology. Soc. Econ. Palaeontol. Mineral. Spec. Publ., 39: 75-81.

Speight, J.G., 1965. Flow and channel characteristics of the Angabunga River. Hydrology, 3: 1-15.

Stene, L.P., 1980. Observations on lateral and overbank deposition - evidence from Holocene terraces in southwestern Alberta. Geology, 8: 314-317.

Stewart, J.H. and Lamarche, V.C., 1967. Erosion and deposition produced by the floods of December 1964 on Coffee Creek, Trinity County, California. U.S. Geol. Surv. Prof. pap., 422K.

Sundborg, A., 1956. The River Klaralven, a study of fluvial processes. Geogr. Annaler, 38: 127-316.

Taylor, G. and Woodyer, K.D., 1978. Bank deposition in suspended load streams. In: A.D. Miall (Editor), Fluvial Sedimentology. Can. Soc. petrol. Geol., Calgary, Mem., 5: 257-275.

Thornbury, W.D., 1969. Principles of Geomorphology. 2nd ed., Wiley, New York.

Thorne, C.R. and Lewin, J., 1979. Bank processes, bed material movement and planform development in a meandering river. In: D.D. Rhodes and G.P. Williams (Editors), Adjustments to the Fluvial System. KendallHunt, Dubque, IA, pp. 117-138.

Ward, R., 1978. Floods: a geographical perspective. Wiley, New York.

Warner, R.F., 1987. Spatial adjustments to temporal variations in flood regime in some Australian rivers. In: K.S. Richards (Editor), River Channels - Environments and Processes. Blackwell, Oxford, pp. 14-39.

Werritty, A. and Ferguson, R.I., 1980. Pattern changes in a Scottish braided river over 130 and 200 years. In: R.A. Cullingford, D.A. Davidson and J. Lewin (Editors), Timescales in Geomorphology. Wiley Chichester, pp. 5368.

Wilcock, D.N., 1967. Coarse bedload as a factor in determining bed slope. Publ. Int. Assoc. Sci. Hydrol., 75: 143-150. Williams, P.E. and Rust, B.R., 1969. The sedimentology of a braided river. J. Sed. Petrol., 39: 549-679. 
Wolman, M.G. and Leopold, L.B., 1957. River floodplains: some observations on their formation. U.S. Geol. Surv. Prof. pap., 282C: 87-107.

Woodroffe, C.D., Chappell, J., Thom, B.G. and Wallensky, E., 1989. Depositional model of a macrotidal estuary and floodplain, South Aligator River, Northern Australia. Sedimentology, 36: 737-756.

Woodyer, K.D., 1975. Concave bank benches on the Barwon River N.S.W. Aust. Geogr., 13: 36-40.

Young, A.R.M., 1986. The geomorphic development of dells (Upland swamps) on the Woronora Plateau, N.S.W., Australia. Z. Geomorph., N.F. 30:3,317-327. 